\section{Journal of Home \\ Economics}

http://homeEcon.menofia.edu.eg

$$
\begin{aligned}
& \text { مجلة الاقتصاد المنزلي } \\
& \text { مجلا 30- عدد يناير - 2020م }
\end{aligned}
$$

ISSN 1110-2578

\title{
الاستفادة من تقتيات استخدام شرائط الكردون والقيطان فى إثراء القيمة الجمالية لملابس السيدات
}

علا يوسف عبداللاه 1 ، نشوه عبدالرؤف توفيق² ، إيمان عبدربه رمضان راشد 3

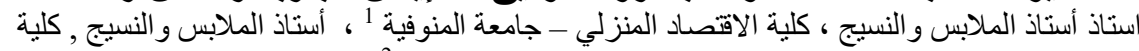
الاقتصاد المنزلى - جادعة المنزي جامعة المنوفية 2

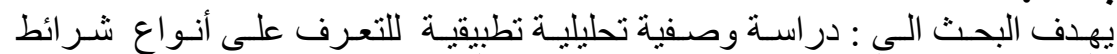

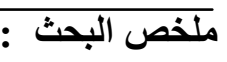

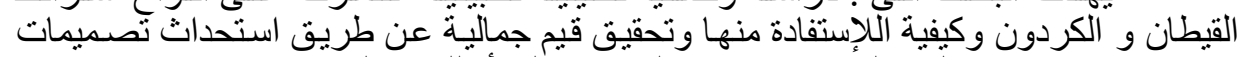

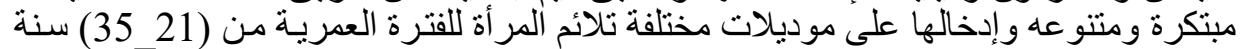
و التعرف على كيفية الدمج بين كل من شر ائط القيطان و الكردون لإثر اء جماليات الملَّس باتباع

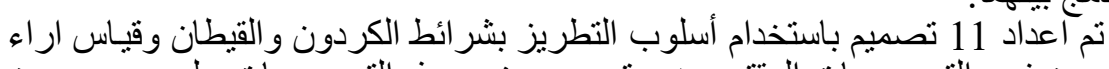

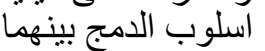

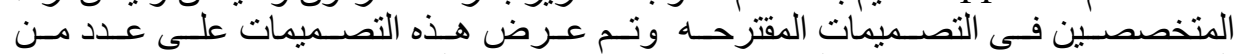

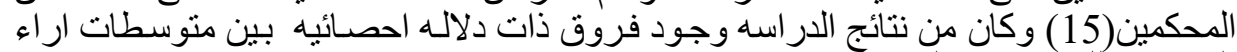
المحكمين للتصميمات المقترحة.

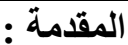

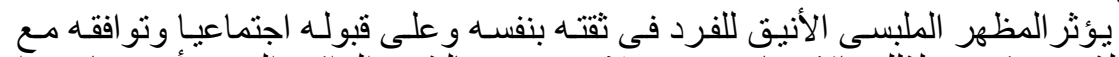

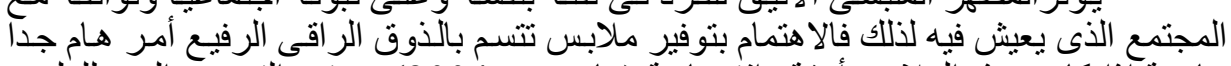

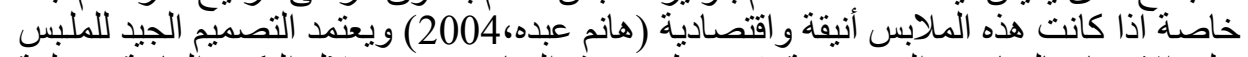

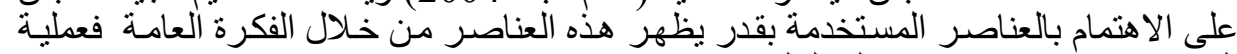

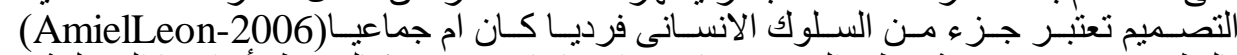

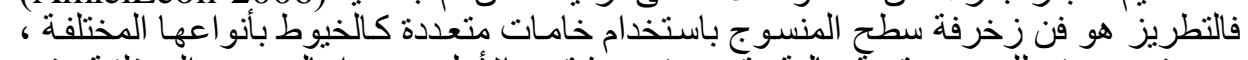

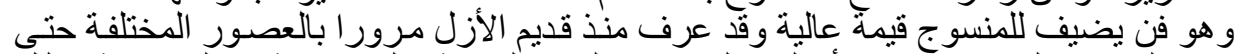

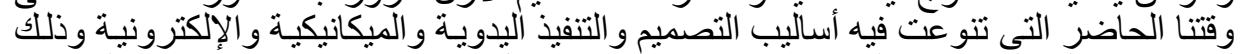

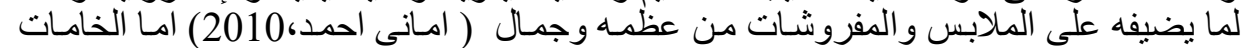

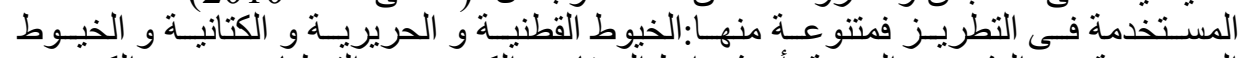

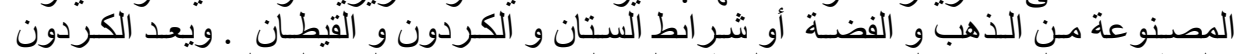

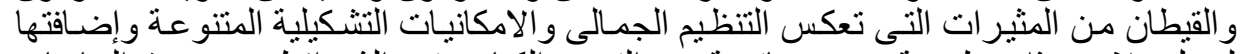

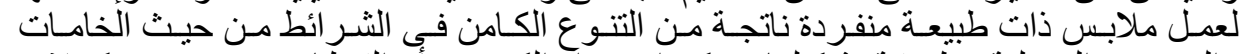

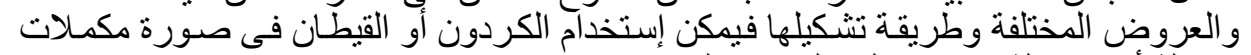

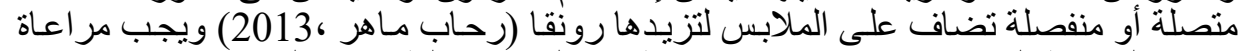

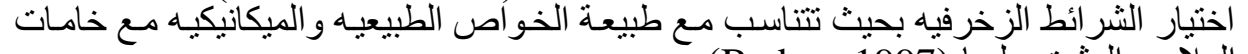

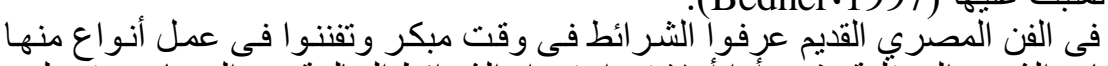

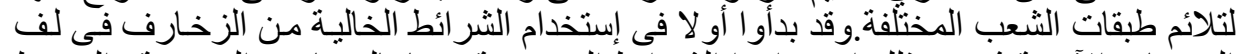

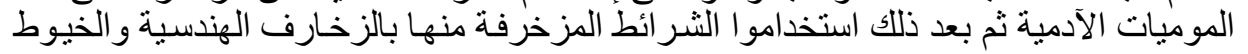




\section{مجلة الاقتصاد المنزلى ـ مجلد (30)- العدد الأول - 2020 م}

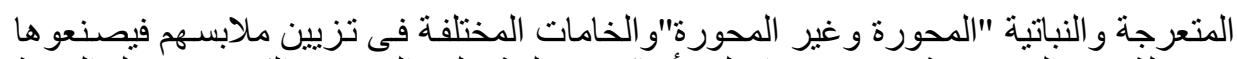

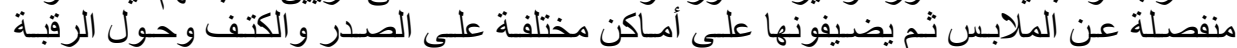

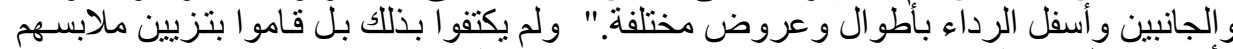

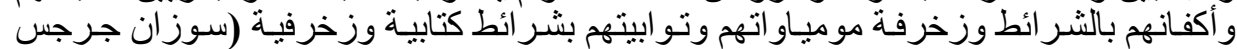

استخذاماتت الثرائط النسيجية:

الثر ائط المنسوجة عامة بات من الصعب الاستغناء عنها في الكثبر من مناحي حياتنا

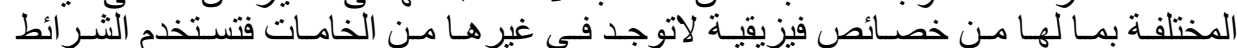

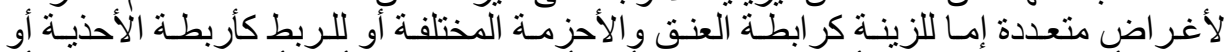

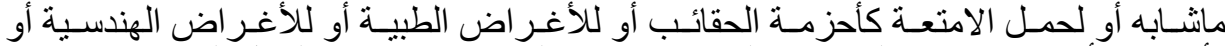

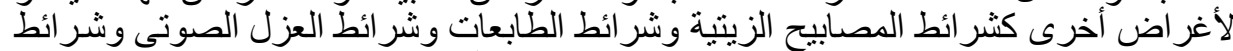

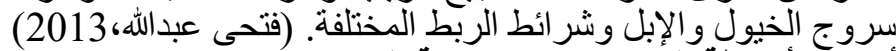
أنواع الأثرطة التى تحتاجها صناعة الإبل الملابن:

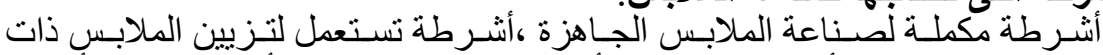

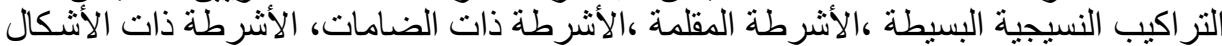

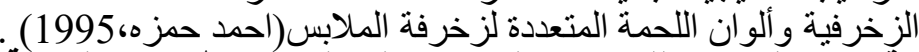

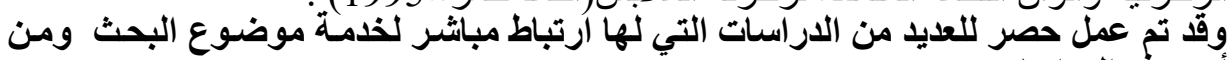

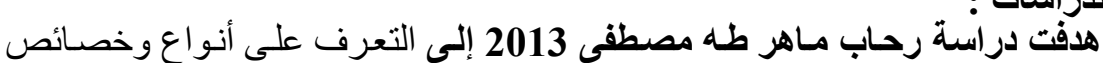

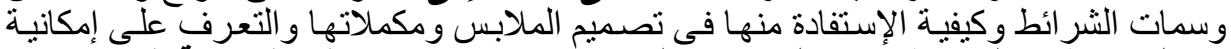

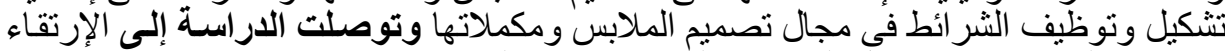

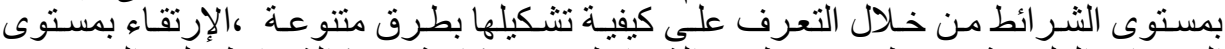

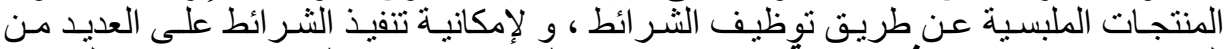

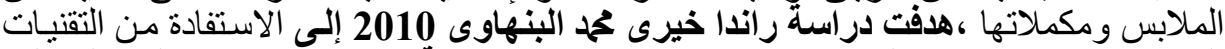

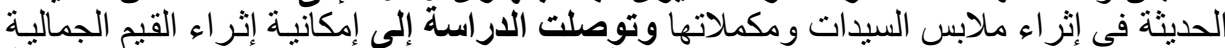

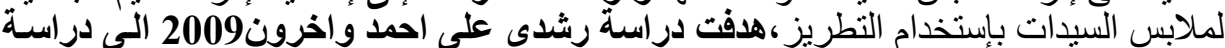

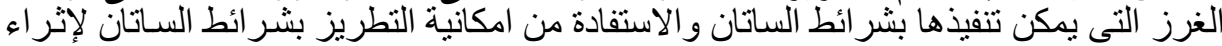

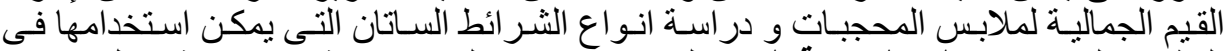

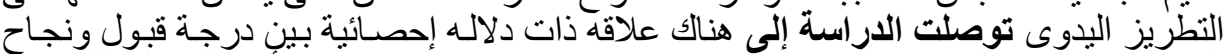

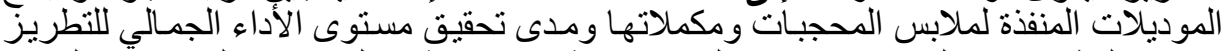

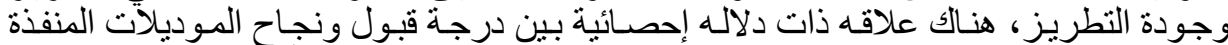

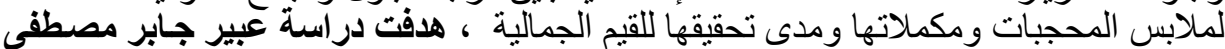

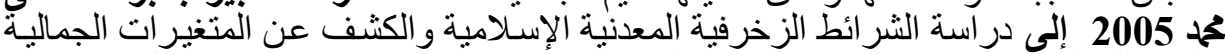

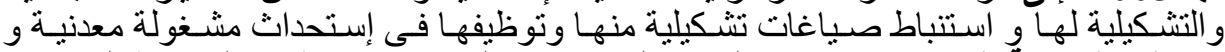

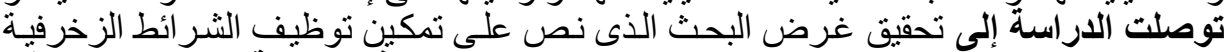

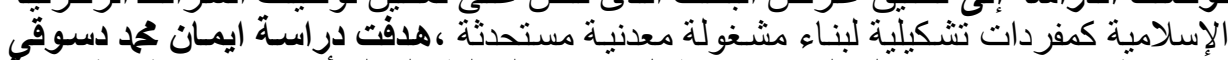

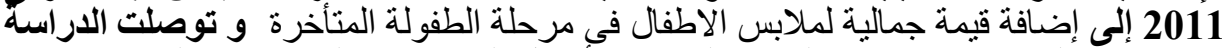

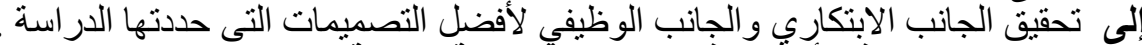

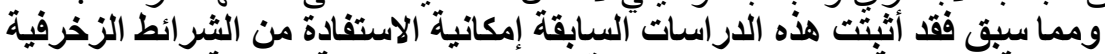

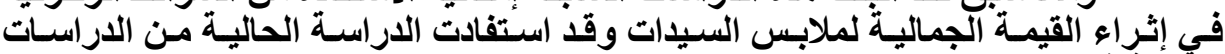

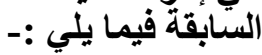




\section{مجلة الاقتصاد المنزلى - مجلد (30)- العدد الأول - 2020 م}

ـكيفية استخدام الشر ائط في تطريز الملابس الاطلاع الدائم على كل ما هو جديد في أشنكال

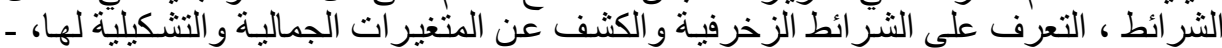
تفسير نتائج البحث الحالي، بناء ادوات التُخ الدراسة.

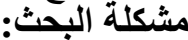

تنلخص مشكلة البحث فى التساؤلات التالية:

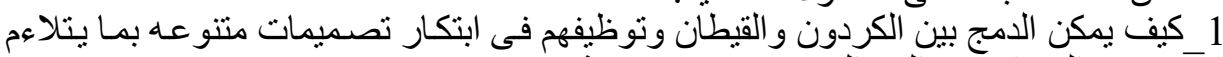

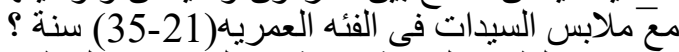

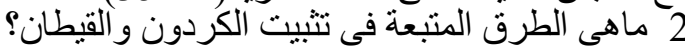

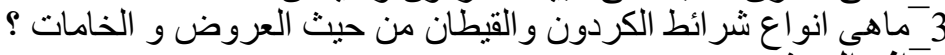

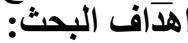
التعرف على انواع القيطان و الكردون وكيفية الاستفادة منها. 1

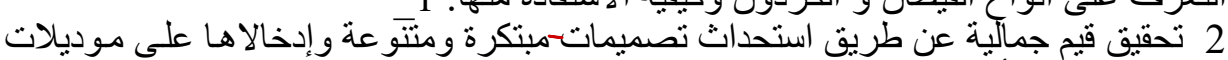

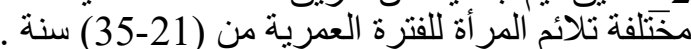
3

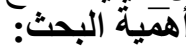

1 الاستفادة من شرائط القيطان والكردون في ابراز الجانب الجمالي لملابس السيدات.

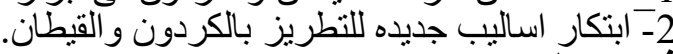

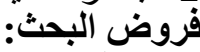

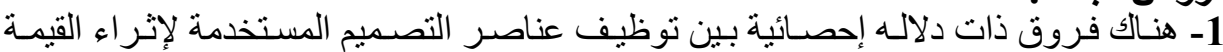

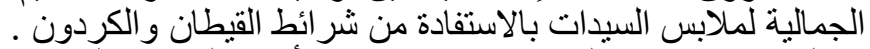

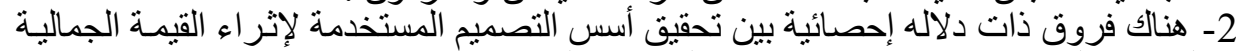

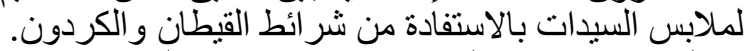

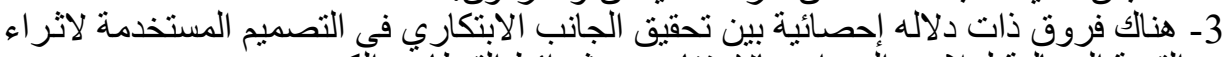

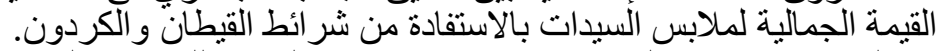

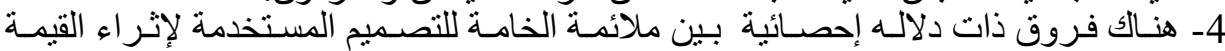

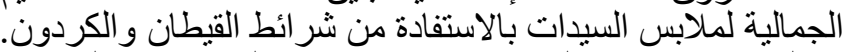

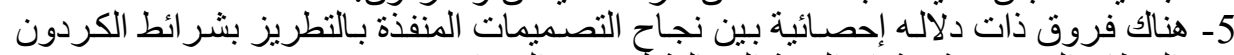

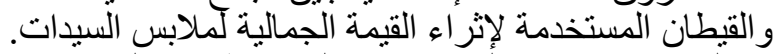

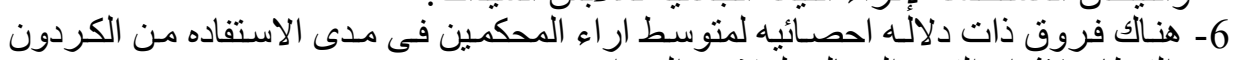

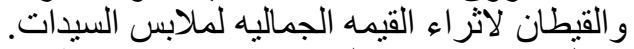

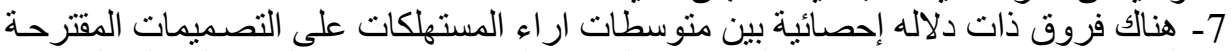

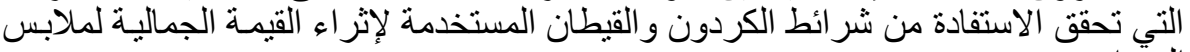

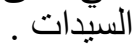

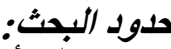

ملابس ألبر أةٌ فى الفئه العمرية (21-35)سنة ، القيطان و الكردون بعروض وخامات مختلفة منهج الببه: البر: ادواثت ألبحث المنهج الوصفي التحليلي التطبيقي او المنهج شبه التجريبى القيطان والبكردون بخامـات وعروض مختلف مجمو عـة ، استمارة استبيان للمتخصصين من

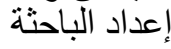
، إستمارة استبيان للمستهلكات من إعداد الباحثة 


\section{مجلة الاقتصاد المنزلى - مجلد (30)- العدد الأول - 2020 م}

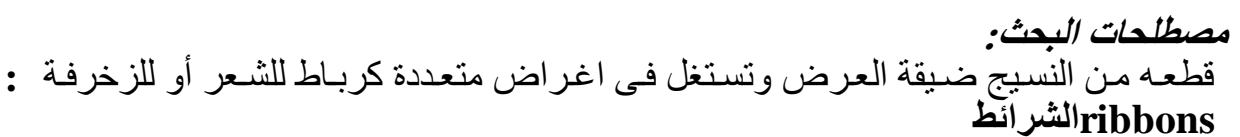

(Jackie\&Daphnet j.Ashby _Woolsey1998

ألتطريز Embroidery

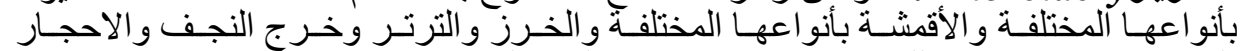

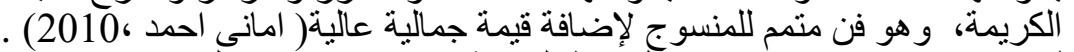

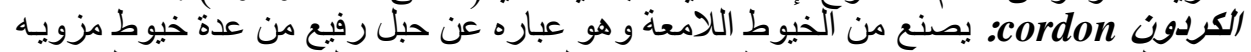

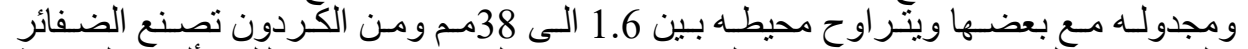

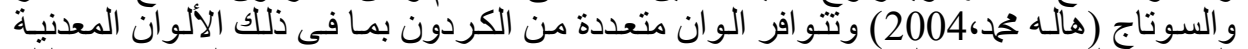

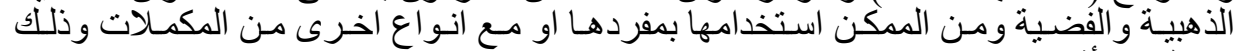

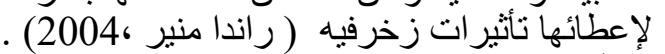

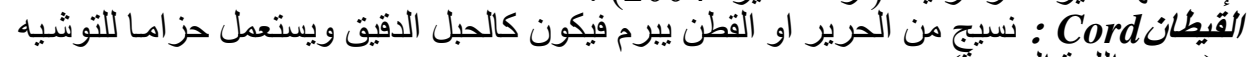

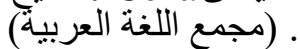

القبيهة الجماليه Aesthetic Value: هى التوافق بين المحتوى الفكري و التشكيلي و التعبيري الفيري

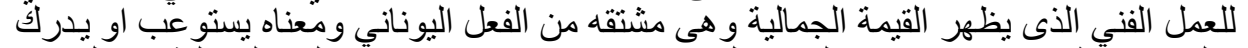

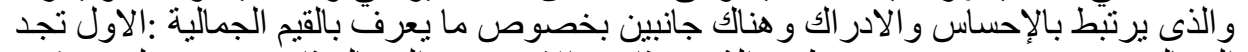

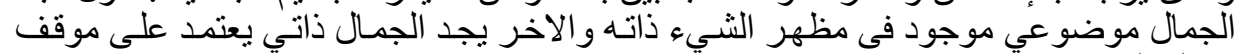

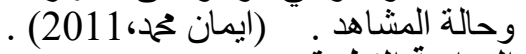
الدراسة النطبيقي

قامت الباحثة بتنفيذّ عدد من التصميمات و عددهم "11" باستخدام شر ائط الكردون و القيطان بما

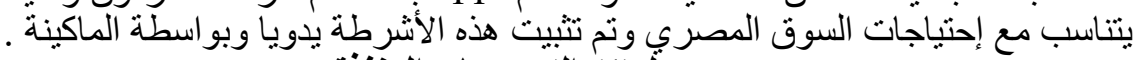

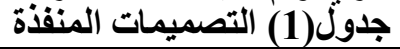

\begin{tabular}{|c|c|c|}
\hline 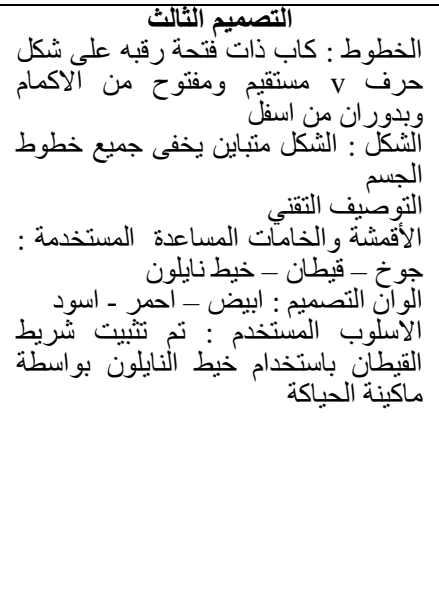 & 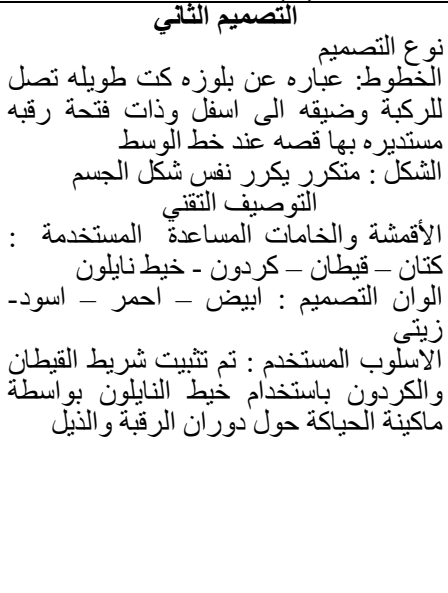 & 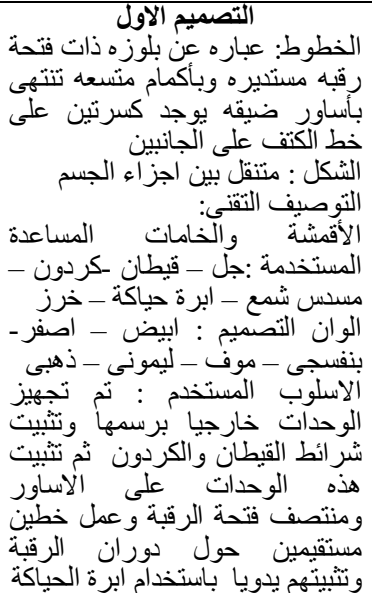 \\
\hline
\end{tabular}




\section{مجلة الاقتصاد المنزلى - مجلا (30)- العدد الأول - 2020 م}

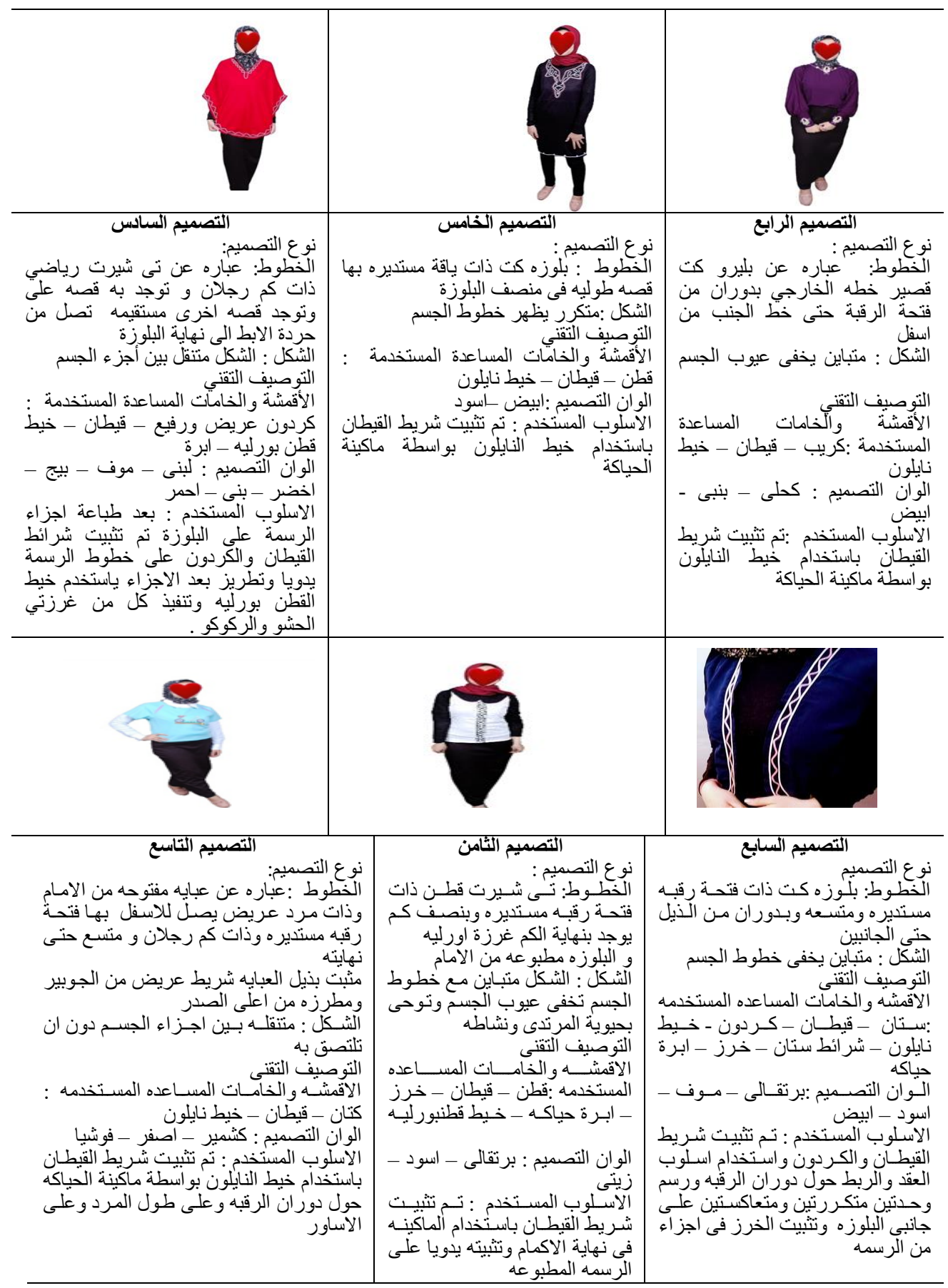


مجلة الاقتصاد المنزلى - مجلا (30)- العدد الأول - 2020 م

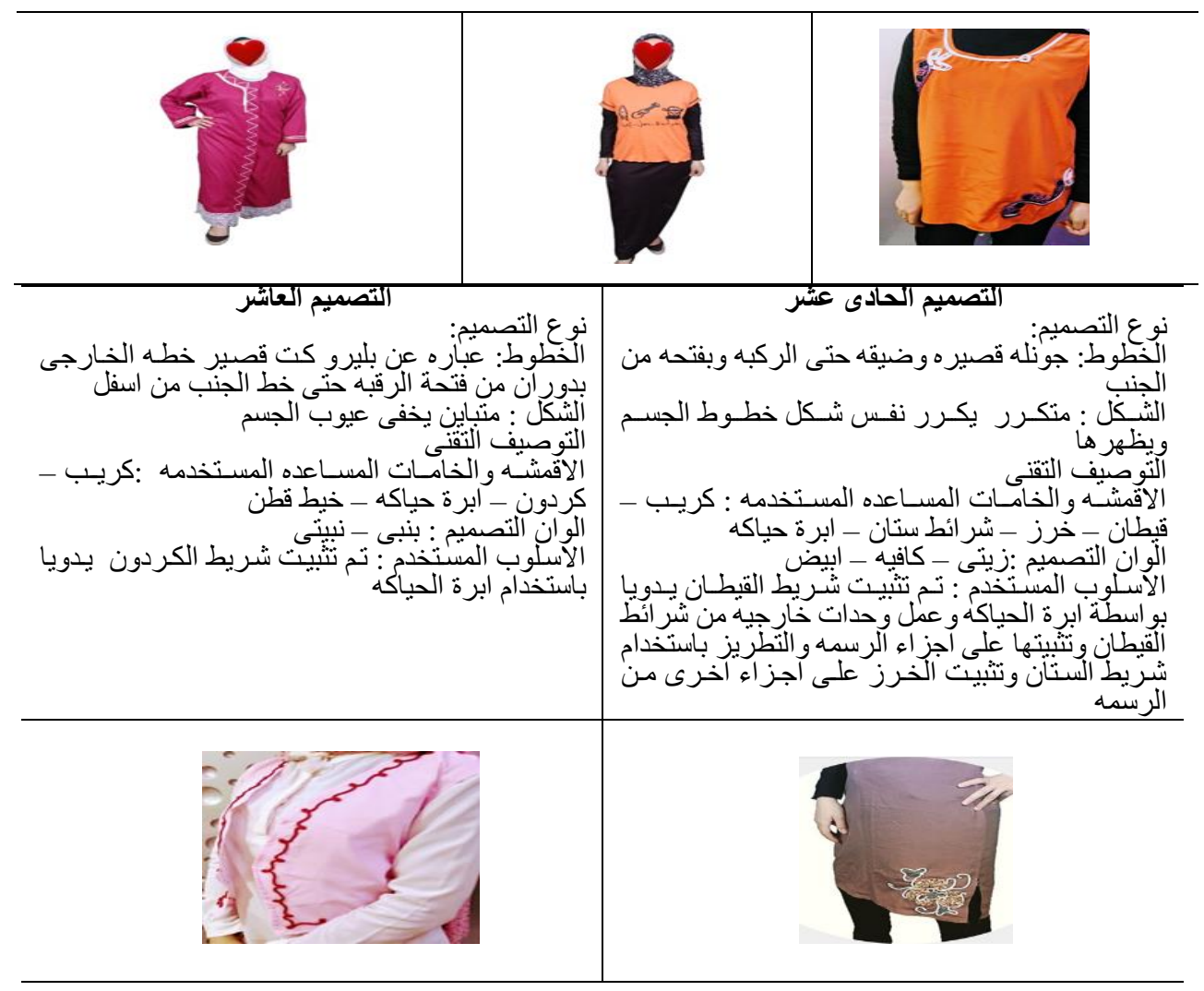

$$
\text { أولاً : صدق الائج والمناقشتة }
$$

1. 1الصدق الظاهري(صدق المتخصيان:

تم عرض الاستبيان فى صورته الأولية على المتخصصين) ف الثين وعددهم(15)محكمين وذلك لإبداء

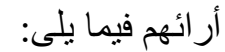

أ. تحديد إنتماء كل بند من بنود الاستبيان للبعد الذي وردت ضمنه أو عدم إنتمائها .

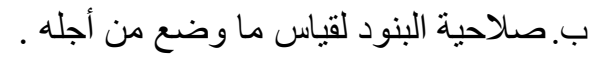

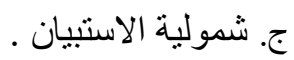

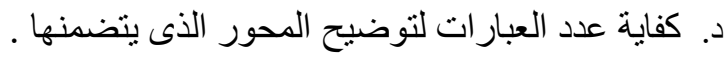
ه. وضوح صياغة كل بند لأفراد العينة و إمكانية تعديل صياغة أو حذف أو أو تبديل بنود جديدة

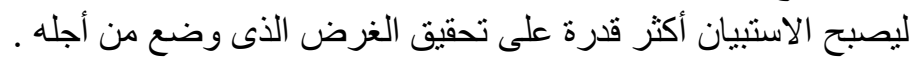


مجلة الاقتصاد المنزلى - مجلد (30)- العدد الأول - 2020 م

جدول (2) نسب الإتفاق بين المحكمين على صلاحية كل عبارة فى الاستبيان

\begin{tabular}{|c|c|c|c|c|c|}
\hline النسبة (\%) & عدد المتفقين & رقم العبارة & النسبة (\%) & عدد المتفقين & رقم العبارة \\
\hline$\% 100$ & 10 & 14 & $\% 100$ & 10 & 1 \\
\hline$\% 90$ & 9 & 15 & $\% 90$ & 9 & 2 \\
\hline$\% 100$ & 10 & 16 & $\% 100$ & 10 & 3 \\
\hline$\% 90$ & 9 & 17 & $\% 80$ & 8 & 4 \\
\hline$\% 100$ & 10 & 18 & $\% 40$ & 4 & 5 \\
\hline$\% 80$ & 8 & 19 & $\% 100$ & 10 & 6 \\
\hline$\% 100$ & 10 & 20 & $\% 90$ & 9 & 7 \\
\hline$\%$ & 9 & 21 & $\% 60$ & 6 & 8 \\
\hline$\% 100$ & 10 & 22 & $\% 100$ & 10 & 9 \\
\hline$\% 90$ & 9 & 23 & $\% 80$ & 8 & 10 \\
\hline$\% 100$ & 10 & 24 & $\% 80$ & 8 & 11 \\
\hline$\% 100$ & 10 & 25 & $\% 100$ & 10 & 12 \\
\hline$\% 80$ & 8 & 26 & $\% 80$ & 8 & 13 \\
\hline
\end{tabular}

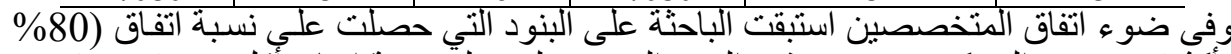

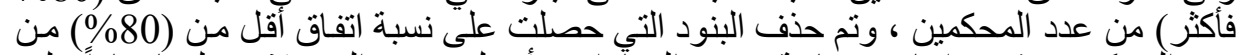

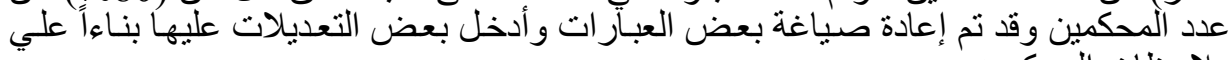

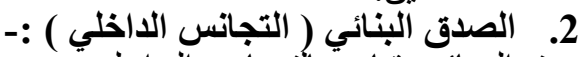

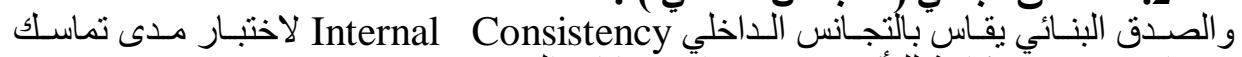
مفرداته. و هى تعد كافية للتأكد من صدق الناني الاستبيانات الجديدة

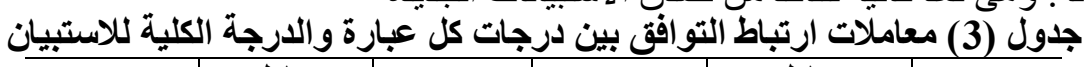

\begin{tabular}{|c|c|c|c|c|c|}
\hline الدلالة & الارتباط معامل & العبارة & الالالة & الارتباط معامل & العبارة \\
\hline 0,000 & $* * 0,656$ & 13 & 0,000 & $* * 0,876$ & 1 \\
\hline 0,000 & $* * 0,687$ & 14 & 0,000 & $* * 0,661$ & 2 \\
\hline 0,000 & $* * 0,691$ & 15 & 0,000 & $* * 0,913$ & 3 \\
\hline 0,000 & $* * 0,640$ & 16 & 0,000 & $* * 0,794$ & 4 \\
\hline 0,000 & $* * 0,795$ & 17 & 0,000 & $* * 0,876$ & 5 \\
\hline 0,000 & $* * \mathbf{0}, 857$ & 18 & 0,000 & $* * 0,676$ & 6 \\
\hline 0,000 & $* * 0,799$ & 19 & 0,000 & $* * 0,820$ & 7 \\
\hline 0,000 & $* * 0,825$ & 20 & 0,000 & $* * 0,756$ & 8 \\
\hline 0,000 & $* * 0,876$ & 21 & 0,000 & $* * 0,932$ & 9 \\
\hline 0,000 & $* * 0,761$ & 22 & 0,000 & $* * 0,741$ & 10 \\
\hline 0,000 & $* * 0,963$ & 23 & 0,000 & $* * 0,787$ & 11 \\
\hline 0,000 & $* * 0,754$ & 24 & 0,000 & $* * 0,740$ & 12 \\
\hline
\end{tabular}

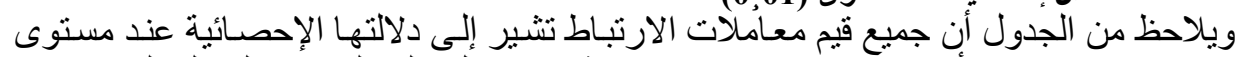

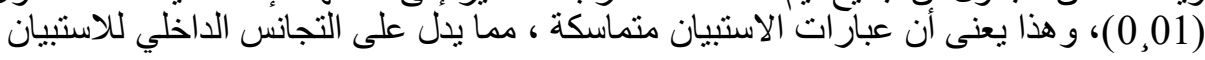


مجلة الاقتصاد المنزلى - مجلد (30)- العدد الأول - 2020 م

جدول (4) معامل الارتباط بين درجة كل عبارة والدرجة الكلية للمحور الذى تنتمى إليه العبارة

\begin{tabular}{|c|c|c|c|c|c|}
\hline الالالة & معامل الارتباط & العبارة & الالالة & معامل الارتباط & ألعبارة \\
\hline 0,000 & $* * 0,650$ & 1 & \multicolumn{3}{|c|}{ المحور الأول } \\
\hline 0,000 & $* * 0,916$ & 2 & $\mathbf{0 , 0 0 0}$ & $* 0,640$ & 1 \\
\hline 0,000 & $*_{0}, 639$ & 3 & $\mathbf{0 , 0 0 0}$ & $* * 0,858$ & 2 \\
\hline 0000 & *\%ण 884 & 4 & 0000 & **0 780 & 3 \\
\hline 01000 & $* * 0.800$ & 5 & 0000 & $* * 0795$ & 4 \\
\hline \multicolumn{3}{|c|}{ المحور أرابع } & & & 5 \\
\hline $\begin{array}{l}0,000 \\
0,000\end{array}$ & $\begin{array}{l}* * 0,784 \\
* * 0) 656\end{array}$ & $\frac{1}{2}$ & \multicolumn{3}{|c|}{ المحور الثانى } \\
\hline 0000 & $* \% 0890$ & 3 & 0000 & $* * 0821$ & 1 \\
\hline 0,000 & **0838 & 4 & 0,000 & $* * 0810$ & 2 \\
\hline \multicolumn{3}{|c|}{ المحور الخخامس } & 0,000 & $* 0.659$ & $\overline{3}$ \\
\hline 0.000 & $* * 0,794$ & 1 & 0,000 & $* * 0721$ & $\frac{4}{4}$ \\
\hline $\mathbf{0 , 0 0 0}$ & $* * 0690$ & 2 & 0,000 & $* 00890$ & 5 \\
\hline 0.000 & $* * 0855$ & 3 & \multirow{3}{*}{\multicolumn{3}{|c|}{ المحور الثالث }} \\
\hline 0,000 & $* * 0,828$ & 4 & & & \\
\hline 0,000 & $* * 0,780$ & 5 & & & \\
\hline
\end{tabular}

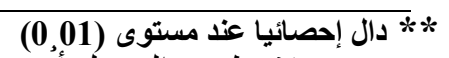

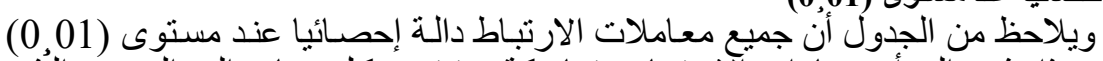

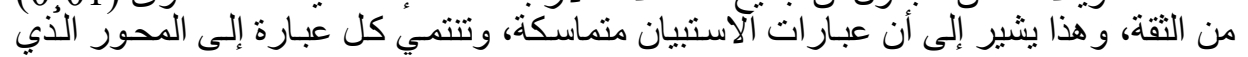

يتضمنها.

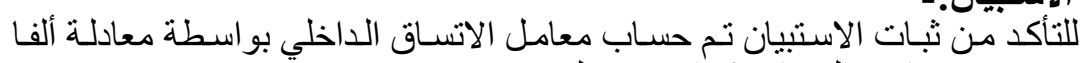
ثُانياً : ثبات الاستبيان:-

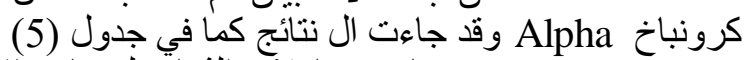

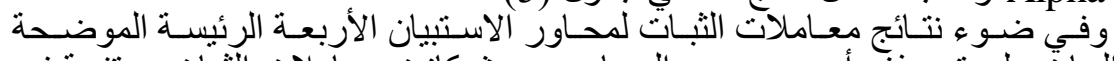

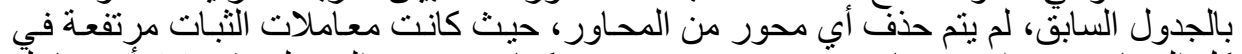

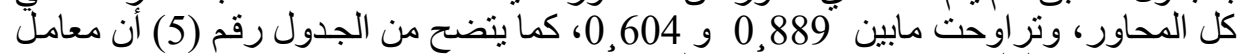

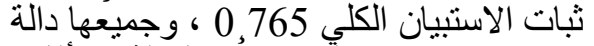
جدول (5) مُعامل الثبات ألفا كرونباخ لمحاور استبيان المحكمين)

\begin{tabular}{|c|c|}
\hline 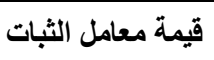 & المحـــــــــــــاور \\
\hline 0,604 & توظيف عناصر التصميم \\
\hline 0,889 & تحقيق اسس التصميم \\
\hline 0,775 & تحقيق الجانب الابتكاري فى التصميم \\
\hline 0,748 & ملائمة الخامه للتصميم \\
\hline 0,812 & نجاح التصميمات المنفذة بالتطريز بشر ائط الكردون و القيطان \\
\hline 0,765 & ثُبات الأداة الكلي \\
\hline
\end{tabular}

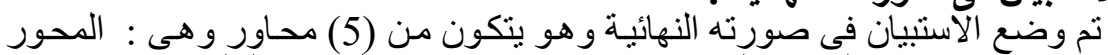

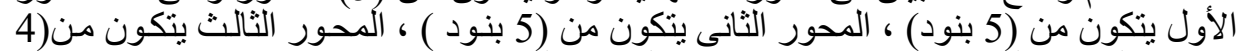

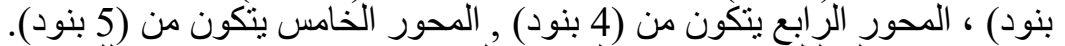

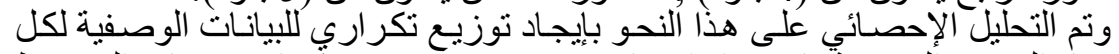

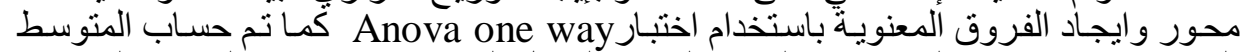

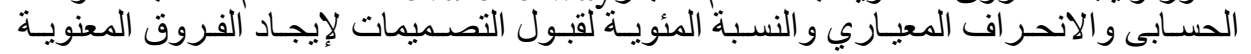


مجلة الاقتصاد المنزلى - مجلد (30)- العدد الأول - 2020 م

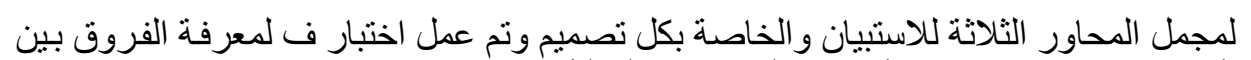

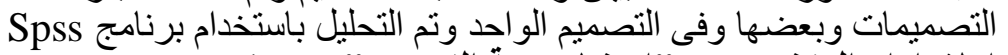

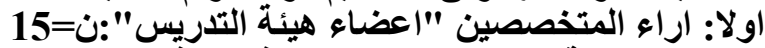

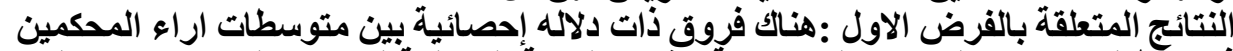

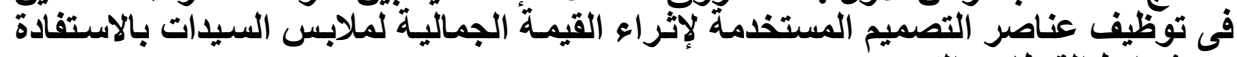
وللتأكد من صحة هذا والفردة الفرض تم حساب المنوسط المرجح و المنوسط المئوى المرجح من شر ائط القيطان والكردون

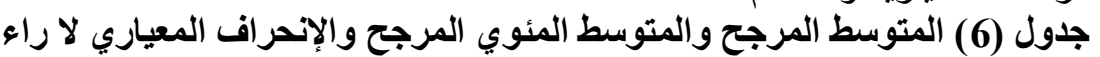

\begin{tabular}{|c|c|c|c|c|c|c|c|c|c|}
\hline \multirow[b]{2}{*}{ التصميمي } & \multirow[b]{2}{*}{ الرئوى } & \multirow[b]{2}{*}{ المعيارى } & \multirow[b]{2}{*}{ المرجح } & \multirow[b]{2}{*}{ الأوزمانٍ } & \multicolumn{3}{|c|}{ مستو يات المؤتُرات } & \multirow[b]{2}{*}{ 帮 } & \multirow[b]{2}{*}{ الدحور الاول } \\
\hline & & & & & $\frac{E}{b}$ & 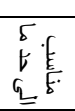 & $\frac{E}{E}$ & & \\
\hline مناسب & $\frac{\% 89.3}{0 / 88.3}$ & $\begin{array}{l}1.19 \\
1.75\end{array}$ & $\frac{2.68}{2.66}$ & $\frac{202}{200}$ & & $\frac{23}{21}$ & $\frac{52}{52}$ & $\frac{1}{2}$ & \\
\hline مناسب & $\frac{\% 88.8}{\% 84}$ & $\begin{array}{l}1.75 \\
1.62\end{array}$ & $\begin{array}{l}2.66 \\
2.52\end{array}$ & $\begin{array}{l}200 \\
188\end{array}$ & 2 & $\begin{array}{l}21 \\
37\end{array}$ & $\frac{52}{38}$ & $\frac{2}{3}$ & \\
\hline مناسب & $\% 86.6$ & 2.84 & 2.6 & 195 & & 30 & 45 & 4 & \\
\hline مناسب & $\% 80$ & 3.80 & 2.4 & 180 & & & 30 & 5 & $E$ \\
\hline مناسب & $\% 88.4$ & 3.12 & 2.65 & 199 & 3 & 20 & 52 & 6 & \\
\hline مناسب حذالى & $\% 68.4$ & 3.52 & 2.05 & 154 & 30 & 19 & 26 & 7 & $\frac{5}{5}$ \\
\hline مناسب & $\% 84.1$ & 2.13 & 2.56 & 189 & & 37 & 38 & 8 & f. \\
\hline مناسب & $\% 80.8$ & 2.72 & 2.42 & 182 & & 43 & 32 & 9 & E: \\
\hline مناسب & $\% 81.7$ & 3.30 & 2.45 & 184 & & 41 & 34 & 10 & $\varphi$ \\
\hline مناسب الى ملى & $\% 73.3$ & 3.17 & 2.2 & 165 & 35 & 25 & 15 & 11 & \\
\hline
\end{tabular}

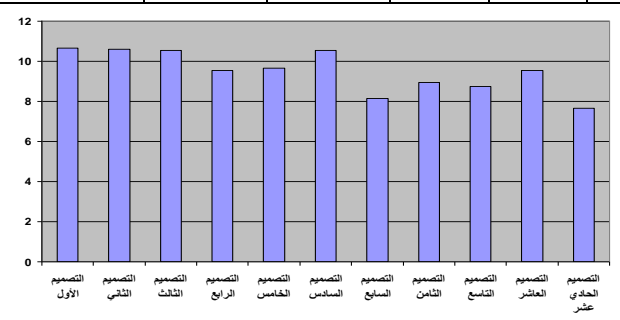

شكل (1) ترتيب التصميمات المقترحة وفق معاملات الجودة لآراء المتخصصين المقترحة لتونة لتوظيف عناصر

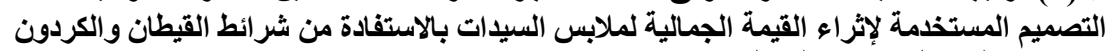

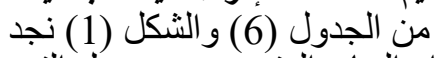

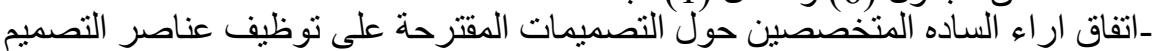

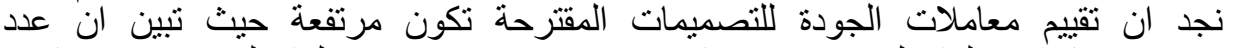

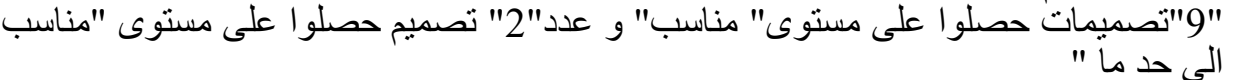

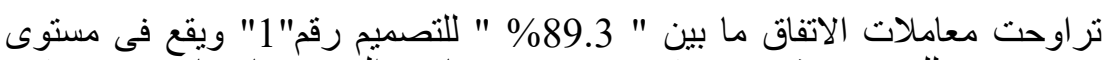

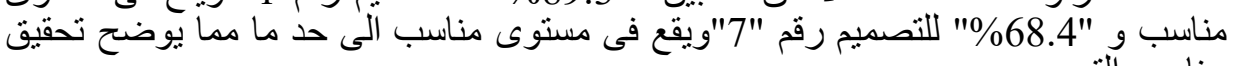




$$
\text { مجلة الاقتصاد المنزلى - مجلد (30)- العدد الأول - } 2020 \text { م }
$$

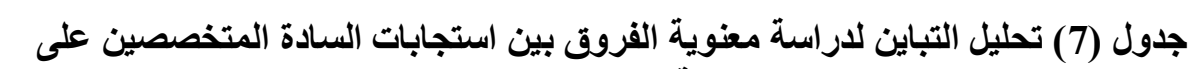
التصميمات المقترحة تبعا لتوظيف عناصر التورين التصميم

\begin{tabular}{|c|c|c|c|c|c|c|c|}
\hline مستوى الالاكل & الدلاله & $\mathbf{F}$ & المربعات & المربعات & الحريه & مصدر التباين & الاستبانه \\
\hline \multirow{3}{*}{0.05} & \multirow{3}{*}{0.022} & \multirow{3}{*}{2.177} & 16.804 & 168.236 & 10 & بين التصميمات & توظيف \\
\hline & & & 7.719 & 1188.667 & 154 & داخل التصميمات & عناصر \\
\hline & & & & 1356.703 & 164 & الاحمالى & التصمبح \\
\hline
\end{tabular}

يوجد فروق ذات دلاله إحصائية عند مستوى دلاله إحصائية "0.05" بين استجابات

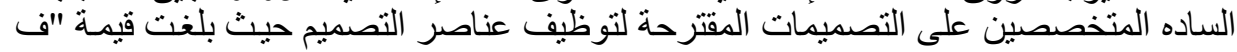

ومستوى الدلالة اقل من مستوى المعنوية "0.05" مما يدل على وجود فروق بين التصميمات

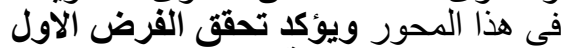

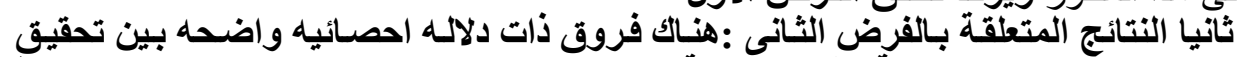

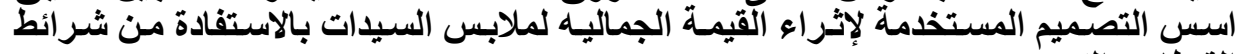

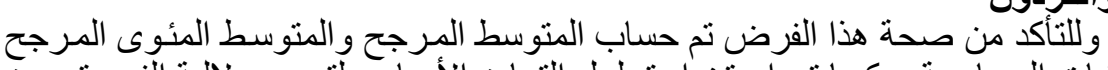
القيطان والكرديمن التصن

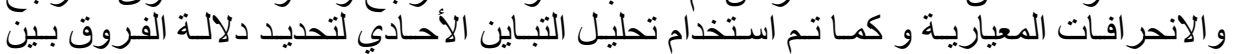
المتوسطات جدول (8) المتوسط المرجح والمتوسط المئوي المرجح والإنحراف المعيارى ب المتخصصين حول التصميمات في تحقيق است التس التصميم

\begin{tabular}{c|c|c|c|c|c|c|c|c|c|}
\hline & & & \\
\end{tabular}

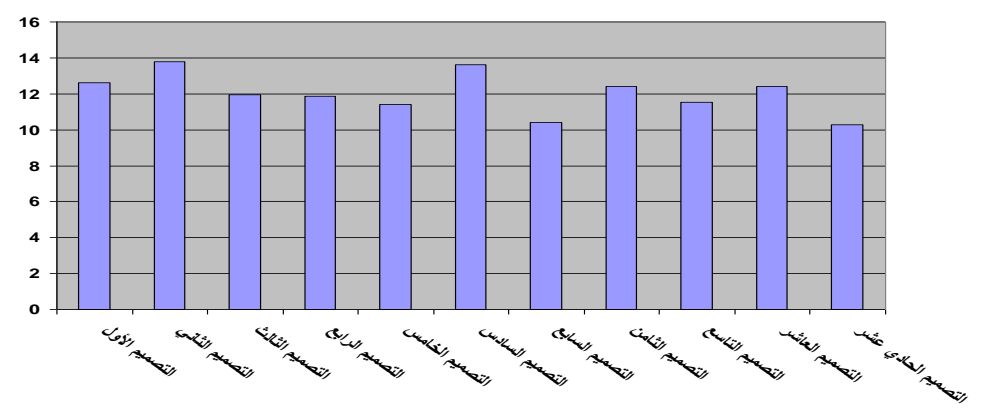

شكل (2) ترتيب التصميمات المقترحة وفق معاملات الجودة لآر اء المتخصصين المقترحة الإتهاء

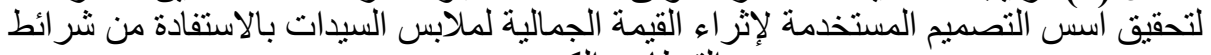

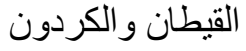


مجلة الاقتصاد المنزلى - مجلد (30)- العدد الأول - 2020 م

من الجدول (8) و الثكل (2) نجد ـاتفاق اراء الساده المتخصصين حول التصديمات التهات المقترحة على تحقيق أسس التصميح

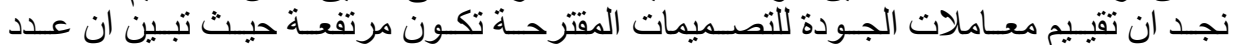

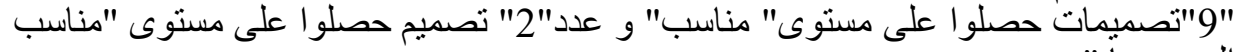

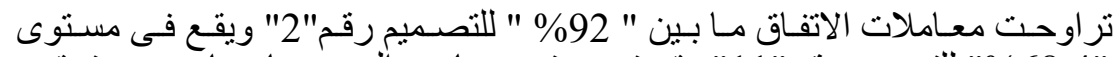

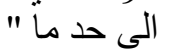

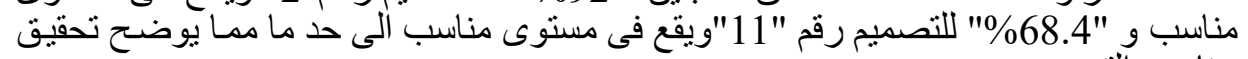

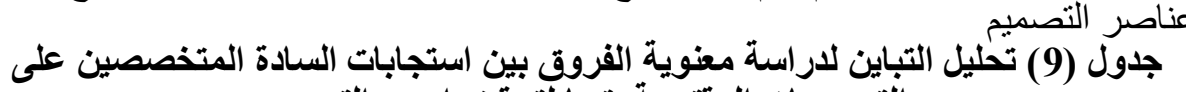

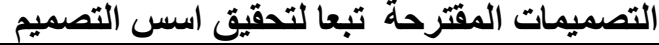

\begin{tabular}{|c|c|c|c|c|c|c|c|}
\hline مستوئ الدالهي & الدلاده & $\mathbf{F}$ & المرتعات & المزبعاتع & الحزيات & مصدر التباين & الاستباتْه \\
\hline \multirow{3}{*}{0.05} & \multirow{3}{*}{0.012} & \multirow{3}{*}{2.391} & 18.961 & 189.612 & 10 & التصبيمات & \multirow{3}{*}{ تالتصقيق أسس } \\
\hline & & & 7.931 & 1221.333 & 154 & التصميملن & \\
\hline & & & & 1410.945 & 164 & الاجمًالى & \\
\hline
\end{tabular}

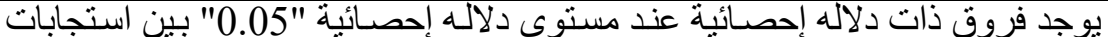

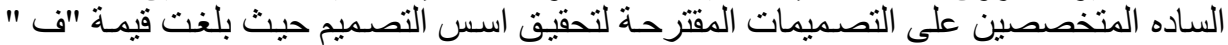

ومستوى الدلالة اقل من مستوى المعنويـة "0.05" مما يدل على وجود فروق بين

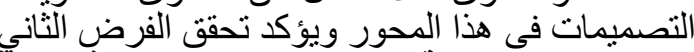

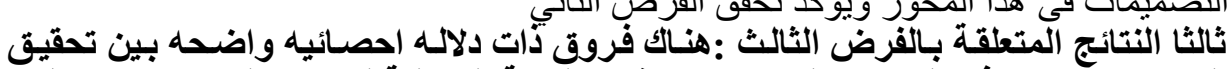

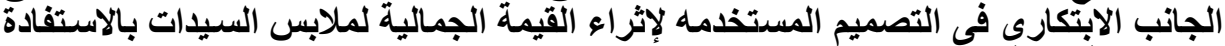
من شرائط القيطان والكردون

وللتأكد من صحة هذا والفردة الفرض تم حساب المتوسط المرجح و المتوسط المئوي المرجح

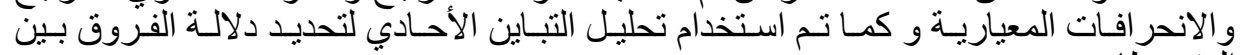

جدول (10) المتوسط المرجح والمتوسط المئوي المرجح والإنحراف المعياري لأراء المتوسطات

\begin{tabular}{|c|c|c|c|c|c|c|c|c|c|}
\hline \multirow[b]{2}{*}{ مستوى التصميم } & \multirow[b]{2}{*}{ المئوى المرجح } & \multirow[b]{2}{*}{ الالانحيارى } & \multirow[b]{2}{*}{ المرجح } & \multirow[b]{2}{*}{ الأوزان } & \multicolumn{3}{|c|}{ مستويات المؤشرات } & \multirow[b]{2}{*}{ |التصميم } & \multirow[b]{2}{*}{ الثالثور } \\
\hline & & & & & غناسب & |الى حذب & ناسب & & \\
\hline مناسب & $\% 82.2$ & 1.83 & 2.46 & 148 & & 32 & 28 & 1 & \\
\hline مناسب & $\% 81.6$ & 1.82 & 2.45 & 147 & 1 & 31 & 28 & 2 & \\
\hline مناسب & $\% 80$ & 1.5 & 2.4 & 144 & 1 & 34 & 25 & 3 & \\
\hline مناسب & $\% 80.5$ & 2.7 & 2.41 & 145 & & 35 & 25 & 4 & تحقيق \\
\hline |مناسب الى حد ما & $\% 75.5$ & 3.4 & 2.26 & 136 & 2 & 40 & 18 & 5 & الجاتب \\
\hline مناسب & $\% 88.8$ & 2.38 & 2.66 & 160 & & 20 & 40 & 6 & ألابتكارى \\
\hline |مناسب الى حد ما & $\% 66.6$ & 2.9 & 2 & 120 & 20 & 20 & 20 & 7 & \\
\hline مناسب & $\% 94.4$ & 1.5 & 2.83 & 170 & & 10 & 50 & 8 & \\
\hline مناسب الى حد ما & $\% 75$ & 1.9 & 2.25 & 138 & 1 & 40 & 19 & 9 & \\
\hline مناسب & $\% 83.3$ & 2.52 & 2.5 & 150 & & 30 & 30 & 10 & \\
\hline مناسب الى حذ ما & \%69.4 & 2.3 & 2.08 & 125 & 20 & 15 & 25 & 11 & \\
\hline
\end{tabular}




\section{مجلة الاقتصاد المنزلى - مجلا (30)- العدد الأول - 2020 م}

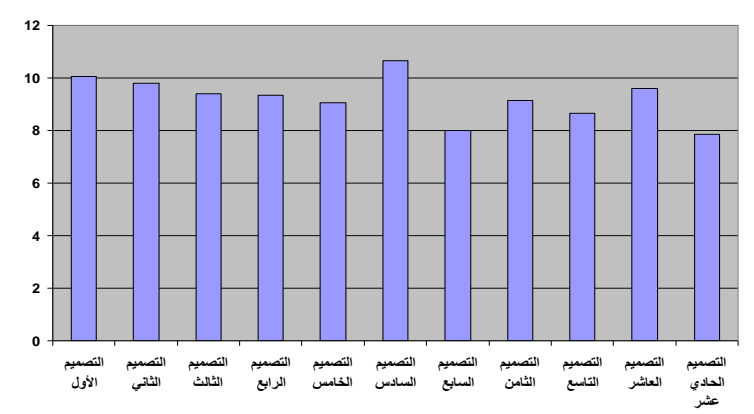

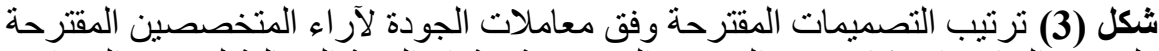

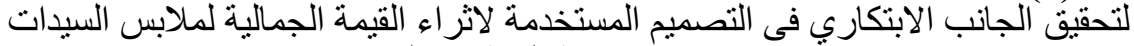
بالاستفادة من شر ائط القيطان و الكردون من الجدول (10) و الثكل (3) نجد ـاتفاق اراء الساده المتخصصين حول التصميمات المقترحة على تحقيق الجانب الابتكاري فى نـ التصمبم

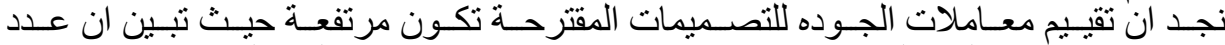

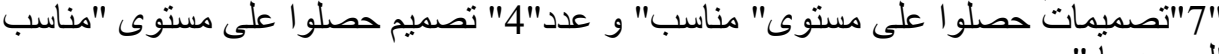

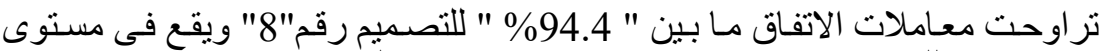
الى حد ماً " التيعات

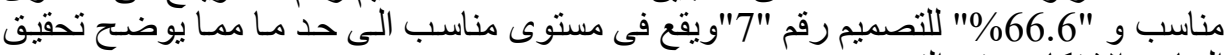
الجانب الابتكاري في التصنيم جدول (11) تحليل التباين لار استة معنوية الفروق بين استجابات السادة المتخصصين على الإنى

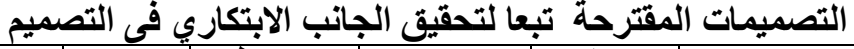

\begin{tabular}{|c|c|c|c|c|c|c|c|}
\hline الدستوى & الدلاله & $\mathbf{F}$ & المربعات & المزبعات & الحريهات & مصدر التباين & الاستبانه \\
\hline \multirow{5}{*}{0.05} & \multirow{5}{*}{0.048} & \multirow{5}{*}{1.906} & 10.485 & 104.848 & 10 & التصمبمات & \multirow{5}{*}{ فلى الابتكارى التصميق } \\
\hline & & & 5.500 & 846.933 & 154 & التصميمات داخل & \\
\hline & & & & 951.782 & 164 & الاجمالىى & \\
\hline & & & 7.947 & 1223.867 & 154 & التصميمات داخل & \\
\hline & & & & 1415.576 & 164 & الاجمالى & \\
\hline
\end{tabular}
يوجد فروق ذات دلاله إحصـائية عند مسنوى دلاله إحصـائية "0.05" بين استجابات

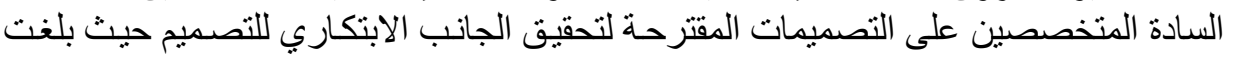
قيمة "ف " 1.906

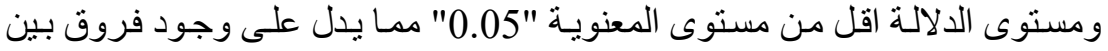

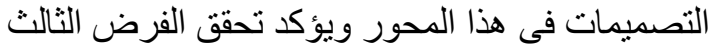


مجلة الاقتصاد المنزلى - مجلد (30)- العدد الأول - 2020 م

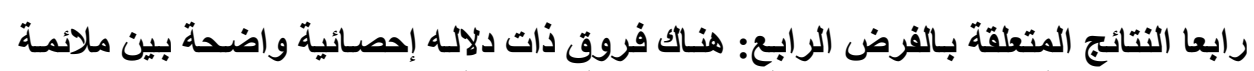

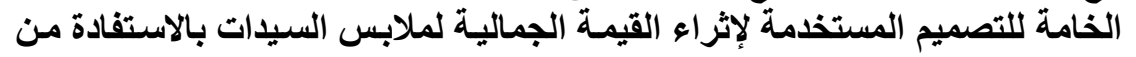

شر ائط القيطان والكردون المبند

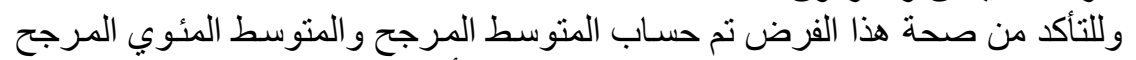

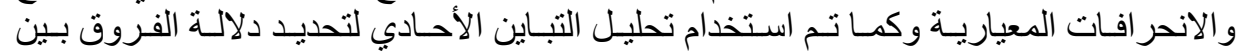

جدول (12) المتوسط المرجح والمتوسط المئوي المرجح والإنحراف المعياري لأراء المتوسطات

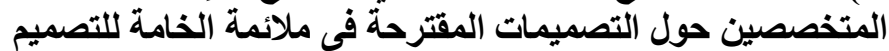

\begin{tabular}{|c|c|c|c|c|c|c|c|c|c|}
\hline \multirow[b]{2}{*}{ التصميم } & \multirow[b]{2}{*}{ المئوى المرجط } & \multirow[b]{2}{*}{ المعيارى الانحراف } & \multirow[b]{2}{*}{ المرجح } & \multirow[b]{2}{*}{ الاوزان } & \multicolumn{3}{|c|}{ مستويات المؤشرات } & \multirow[b]{2}{*}{ التصميم } & \multirow[b]{2}{*}{ الرحابع } \\
\hline & & & & & مناسير & مناسب & مناسب & & \\
\hline مناسب & $\% 92.2$ & 1.6 & 2.76 & 166 & & 14 & 46 & 1 & \multirow{11}{*}{ للتصائمة } \\
\hline مناسب & $\% 91.3$ & 1.63 & 2.73 & 165 & & 18 & 42 & 2 & \\
\hline مناسب & $\% 89.4$ & 1.5 & 2.68 & 161 & 1 & 17 & 42 & 3 & \\
\hline مناسب & $\% 85.5$ & 2.4 & 2.56 & 154 & 1 & 24 & 35 & 4 & \\
\hline مناسب & $\% 82.7$ & 3.1 & 2.4 & 148 & & 32 & 28 & 5 & \\
\hline مناسب & $\% 91.1$ & 2.35 & 2.73 & 164 & 1 & 17 & 42 & 6 & \\
\hline الى حدن ما & $\% 75.1$ & 2.6 & 2.25 & 138 & 18 & 6 & 36 & 7 & \\
\hline مناسب & $\% 83.3$ & 1.5 & 2.5 & 150 & & 30 & 30 & 8 & \\
\hline مناسب & $\% 80$ & 2.01 & 2.4 & 144 & 1 & 34 & 25 & 9 & \\
\hline مناسب & $\% 94.4$ & 2.64 & 2.8 & 170 & & 10 & 50 & 10 & \\
\hline الى حذاسب ما & 75 & 2.3 & 2.25 & 135 & 16 & 13 & 31 & 11 & \\
\hline
\end{tabular}

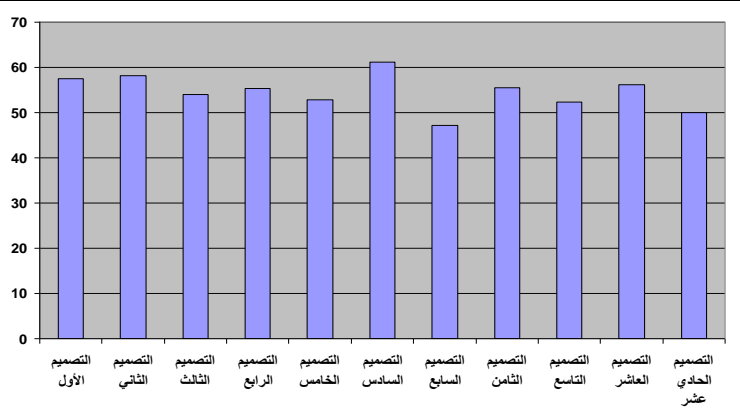

شكل (4) ترتيب التصميمات المقترحة وفقي معاملات الجودة لآر اء المتخصصين المقترحة

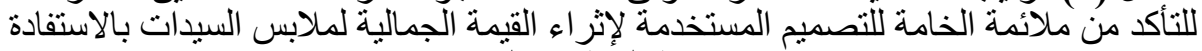
من شر ائط القيطان و الكردون الفئن من الجدول (12) و الثكل (4) نجد ـاتفاق اراء السادة المتخصصين حول النحل التصميمات المقترحة على ملائمة الخامة للتصميح

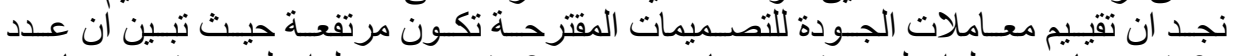

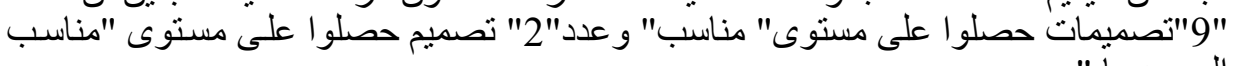


مجلة الاقتصاد المنزلى - مجلد (30)- العدد الأول - 2020 م

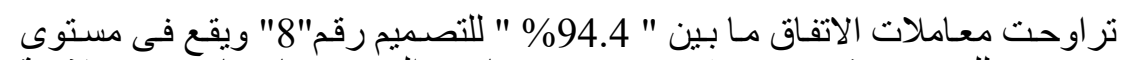

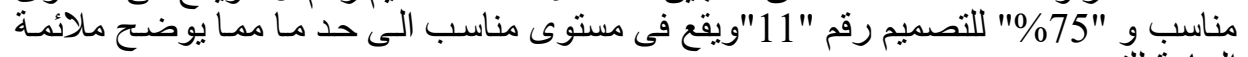

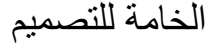

جدول (13) تحليل التباين لاراسة معنوية الفروق بين استجابات السادة المتخصصين على المئل

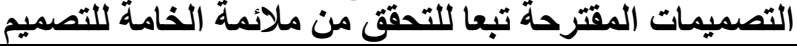

\begin{tabular}{|c|c|c|c|c|c|c|c|}
\hline مستوى الدلاله & الدلاله & $\mathbf{F}$ & المربعات & المربعات & الحريه & مصدر التباين & الاستباته \\
\hline \multirow{3}{*}{0.05} & \multirow{3}{*}{0.001} & \multirow{3}{*}{3.262} & 16.312 & 163.115 & 10 & التصميمات & \multirow{3}{*}{ للائمة الخامة } \\
\hline & & & 5.001 & 770.133 & 154 & التصميمات & \\
\hline & & & & 933.248 & 164 & الاجمالى & \\
\hline
\end{tabular}

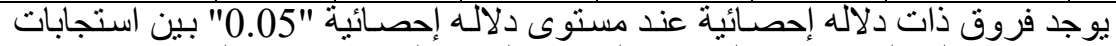

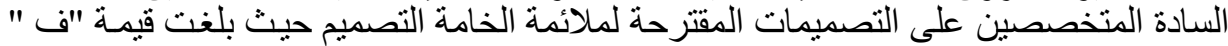

0.001

ومستوى الدلالة اقل من مستوى المعنويـة "0.05" ممـا يدل على وجود فروق بين

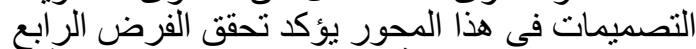

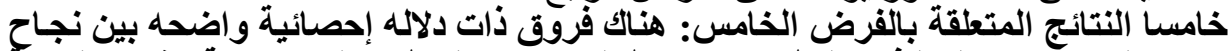

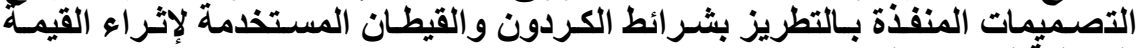

الجمالية لملابس الميدات المبات التطري

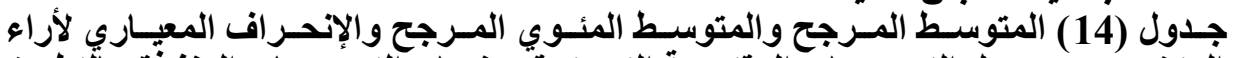

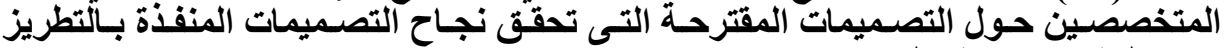

\begin{tabular}{|c|c|c|c|c|c|c|c|c|c|}
\hline \multirow[b]{3}{*}{ التصميم } & \multirow{3}{*}{ المئوى المتح } & \multirow{3}{*}{ المعيارى } & \multirow[b]{3}{*}{ المرجح } & \multirow[b]{3}{*}{ الاوزان } & \multicolumn{5}{|c|}{ بشر ائط الكردون والقيطان } \\
\hline & & & & & \multicolumn{3}{|c|}{ مستويات المؤشرات } & \multirow[b]{2}{*}{ | التصميم | } & \multirow[b]{2}{*}{ الخامس } \\
\hline & & & & & |غناسب & |لى حذا & مناسب & & \\
\hline مناسب & $\% 88.8$ & 2.03 & 2.6 & 200 & 1 & 23 & 51 & 1 & \multirow{11}{*}{ التصنيماح } \\
\hline مناسب & $\% 95.5$ & 2.25 & 2.8 & 215 & & 10 & 65 & 2 & \\
\hline مناسب & $\% 84.4$ & 1.9 & 2.5 & 190 & & 35 & 40 & 3 & \\
\hline مناسب & $\% 81.7$ & 2.7 & 2.45 & 184 & & 41 & 34 & 4 & \\
\hline مناسب & $\% 88.4$ & 3.6 & 2.65 & 199 & 2 & 22 & 51 & 5 & \\
\hline مناسب & $\% 84$ & 2.8 & 2.5 & 189 & & 36 & 39 & 6 & \\
\hline مناسب & $\% 80$ & 3.6 & 2.4 & 180 & 2 & 41 & 32 & 7 & \\
\hline مناسب & $\% 991.1$ & 2.26 & 2.7 & 205 & 1 & 18 & 56 & 8 & \\
\hline مناسب & $\% 82.2$ & 2.69 & 2.46 & 186 & 1 & 37 & 37 & 9 & \\
\hline مناسب & $\% 93.3$ & 3.28 & 2.8 & 210 & & 12 & 63 & 10 & \\
\hline مناسب الى ملى & $\% 68.8$ & 2.9 & 2.06 & 155 & 25 & 30 & 20 & 11 & \\
\hline
\end{tabular}




\section{مجلة الاقتصاد المنزلى - مجلا (30)- العدد الأول - 2020 م}

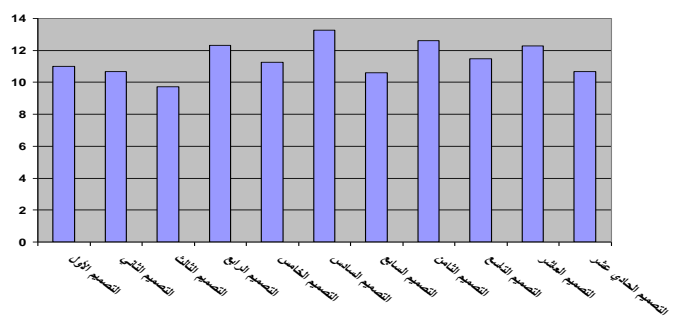

شكل (5) ترتيب التصميمات المقترحة وفق معاملات الجودة لار اء المتخصصين المقترحة في تحقيق نجاح التصميمات المنفذة بالنطريز بشر ائط الكردون والقيط التيطان المستخدمة لإثراء القيمة القيمة الجمالية لملابس السيدات النرات من الجدول (14) و الثكل (5) نجد

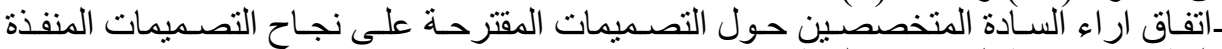
بالتطريز بشر ائط الكردون والقيط القيطان

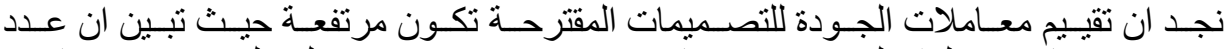

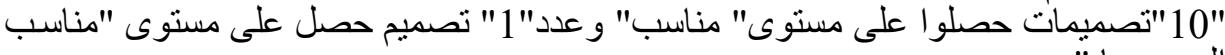

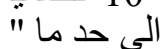

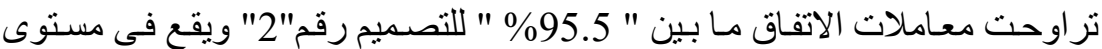

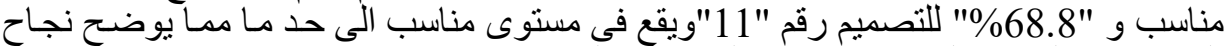
التصميمات المنفذة بالتطريز بشر ائط الكردون وائب والقيطان

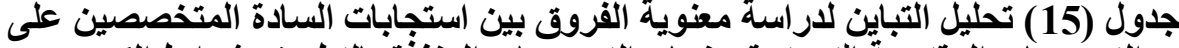
التصميمات المقترحة التي تحقق نجاح التصميمات المنفذة بالتطريز بشرائط الكردون والقيطان

\begin{tabular}{|c|c|c|c|c|c|c|c|}
\hline مستوى الدلاله & الدلاله & $\mathbf{F}$ & متوسطات & المربعات & الرجيه & مصدر & محور الاستبانه \\
\hline \multirow[t]{3}{*}{0.05} & \multirow[t]{3}{*}{0.011} & \multirow[t]{3}{*}{2.412} & 19.171 & 191.709 & 10 & التصميمات & \multirow{3}{*}{ 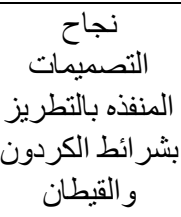 } \\
\hline & & & 7.947 & 1223.867 & 154 & التصميمات & \\
\hline & & & & 1415.576 & 164 & الاجمالى & \\
\hline
\end{tabular}

يوجد فروق ذات دلاله إحصائية عند مستوى دلاله إحصائية "0.05" بين استجابات

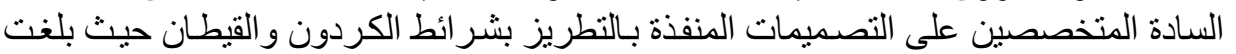

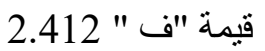

ومستوى الدلالة اقل من مستوى المعنويـة "0.05" ممـا يدل على وجود فروق بين

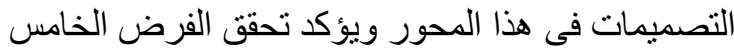

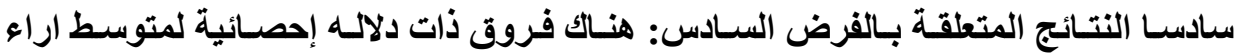

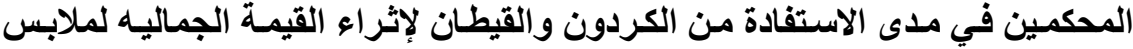
السيدات وللتأكد من صحة هذا الفرض تم حساب المتوسط المرجح و المتوسط المئوى المرجح

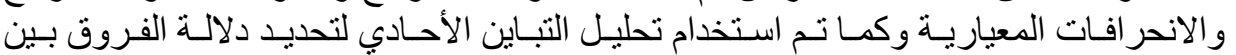
المتوسطات 
مجلة الاقتصاد المنزلى - مجلد (30)- العدد الأول - 2020 م

جدول (16) المتوسط المرجح والمتوسط المئوي المرجح والإنحراف المعياري لأراء

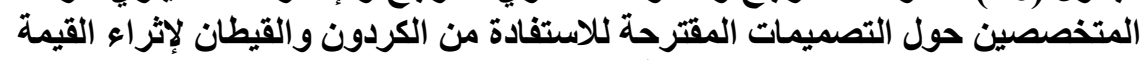

\begin{tabular}{|c|c|c|c|c|c|c|c|c|}
\hline \multirow{2}{*}{ التصميم } & \multirow{2}{*}{ المئوى المتوج } & \multirow{2}{*}{ المعيارى الانحراف } & \multirow{2}{*}{ المرجح } & \multirow{2}{*}{ الاوزان } & \multicolumn{3}{|c|}{ مستويات المؤشرات } & \multirow[t]{2}{*}{ التصميم } \\
\hline & & & & & غناسب & مناسب & مناسب & \\
\hline مناسب & \%89.1 & 6.9 & 2.67 & 923 & & 128 & 217 & 1 \\
\hline مناسب & $\% 89.3$ & 13.03 & 2.68 & 925 & 3 & 98 & 244 & 2 \\
\hline مناسب & $\% 83.5$ & 7.6 & 2.5 & 865 & 4 & 163 & 178 & 3 \\
\hline مناسب & $\% 82.8$ & 11.5 & 2.68 & 858 & 3 & 171 & 171 & 4 \\
\hline مناسب & $\% 82.1$ & 16.5 & 2.4 & 850 & 4 & 175 & 166 & 5 \\
\hline مناسب & $\% 88.5$ & 8.27 & 2.65 & 916 & 3 & 116 & 226 & 6 \\
\hline مناسب الى مد & $\% 72.2$ & 16.07 & 2.16 & 748 & 100 & 98 & 147 & 7 \\
\hline مناسب & $\% 86.9$ & 7.98 & 2.6 & 900 & 4 & 133 & 208 & 8 \\
\hline مناسب & $\% 80.1$ & 12.3 & 2.4 & 830 & 4 & 198 & 143 & 9 \\
\hline مناسب & $\% 87$ & 14.64 & 2.6 & 901 & 1 & 130 & 214 & 10 \\
\hline مناسب الى ما & $\% 58.3$ & 16.20 & 1.75 & 604 & 129 & 120 & 96 & 11 \\
\hline
\end{tabular}

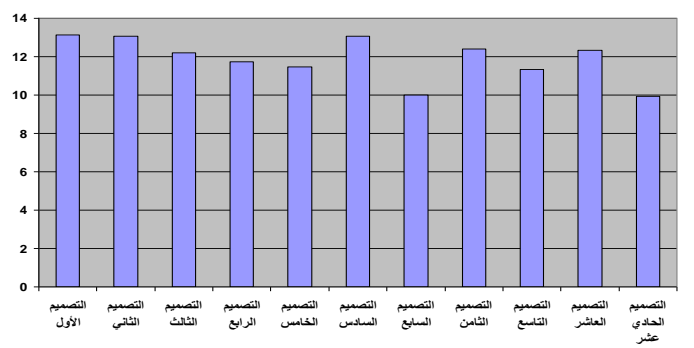

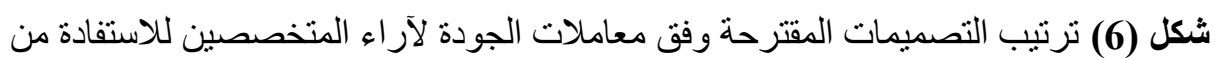

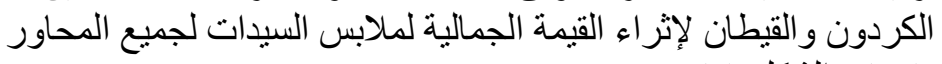
من الجدول (16) و الثنكل (6) نجد الإند

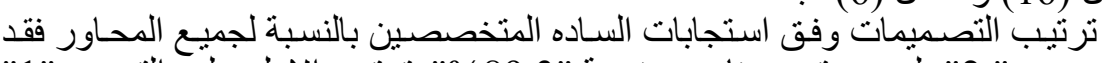

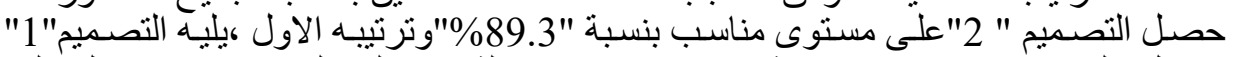

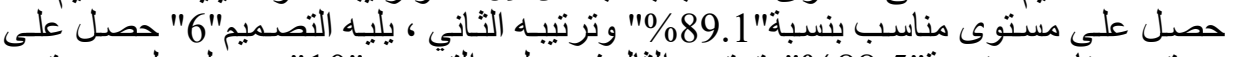

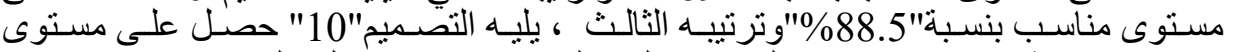

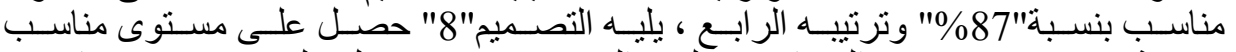

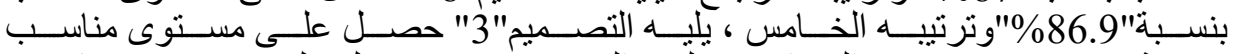

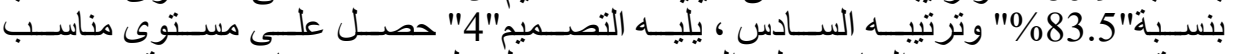

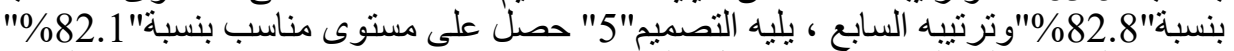

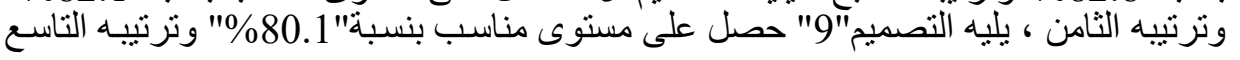


مجلة الاقتصاد المنزلى - مجلد (30)- العدد الأول - 2020 م

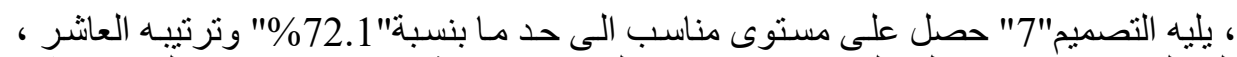

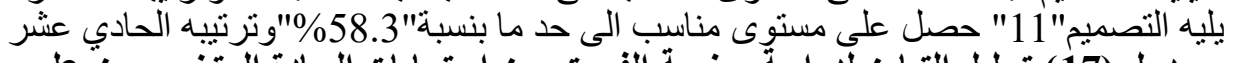

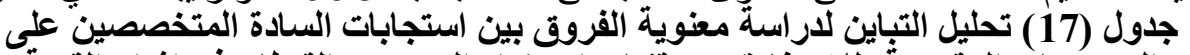

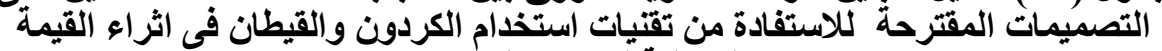

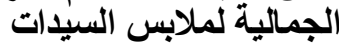

\begin{tabular}{|c|c|c|c|c|c|c|c|}
\hline مستوى الدلاله & الدلاله & $\mathbf{F}$ & المربعات & مجموع المربعات & الحرجيه & مصدر التباين & الاستبانه ككل \\
\hline \multirow{3}{*}{0.05} & \multirow{3}{*}{0.04} & \multirow{3}{*}{1.480} & 229.059 & 2290.594 & 10 & بين التصميمات & \multirow{3}{*}{ 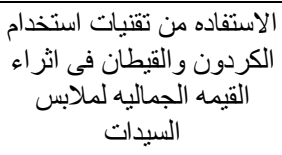 } \\
\hline & & & 154.730 & 23828.400 & 154 & داخل التصميمات & \\
\hline & & & & 26118.994 & 164 & الاجمالى & \\
\hline
\end{tabular}

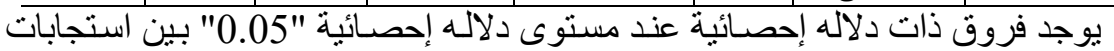

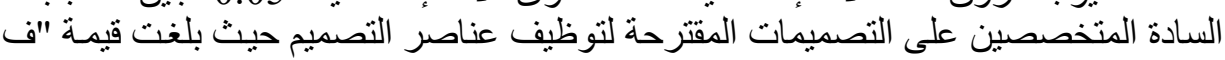
$1.480 "$

ومستوى الدلالـة اقل من مستوى المعنويـة "0.05" ممـا يـل على على وجود فروق بين

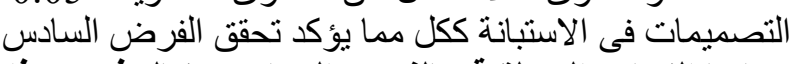

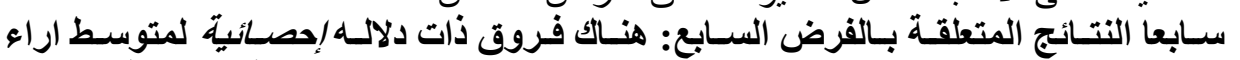

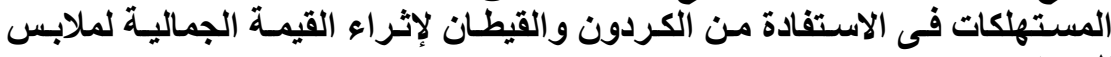

\section{السيدات المبكات}

النتائج المتعلقة بـأراء المستهاتكات فى مدى الاستفادة من الكردون والقيطان لإثراء القيمة

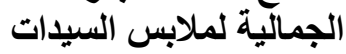

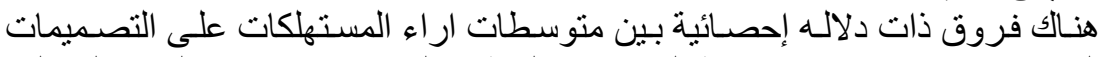

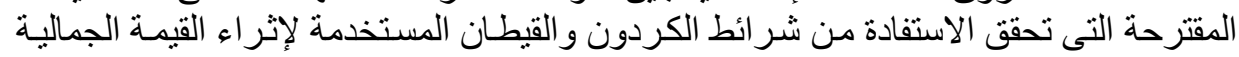
لملابس السيدات

وللتأكد من صحة هذا الفرض تم حساب المتوسط المرجح و المتوسط المئوي المرجح

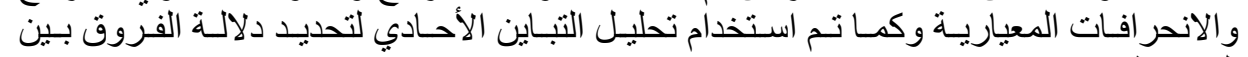

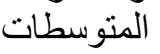
جدول (18) المتوسط المرجح والمتوسط المئوي المرجح والإنحراف المعياري لأراء المستهلكات حول

\begin{tabular}{|c|c|c|c|c|c|c|c|c|}
\hline \multirow[b]{2}{*}{ التصنتوى } & \multirow{2}{*}{ المئوى المتوسط } & \multirow[b]{2}{*}{ المعيارى } & \multirow[b]{2}{*}{ المرجح } & \multirow[b]{2}{*}{ الاوزان } & \multicolumn{3}{|c|}{ مستويات المؤشرات } & \multirow[b]{2}{*}{ التصميم } \\
\hline & & & & & مناسبي & |الى حناسب ما & مناسب & \\
\hline مناسب & $\% 95.8$ & 2.19 & 208 & 1466 & & 253 & 320 & 1 \\
\hline هناسب & $\% 94.3$ & 3.2 & 2.8 & 1443 & & 174 & 365 & 2 \\
\hline مناسب & $\% 92.8$ & 2.96 & 2.78 & 1420 & & 218 & 328 & 3 \\
\hline مناسب & $\% 89.8$ & 2.6 & 2.7 & 1375 & 3 & 251 & 290 & 4 \\
\hline هناسب & $\% 97.7$ & 3.83 & 2.9 & 1495 & & 209 & 359 & 5 \\
\hline مناسب & \%87.9 & 3.08 & 2.6 & 1345 & 2 & 154 & 345 & 6 \\
\hline مناسب & $\% 82$ & 3.5 & 2.46 & 1255 & 135 & 324 & 216 & 7 \\
\hline مناسب & \%92.4 & 3.04 & 2.7 & 1415 & & 235 & 315 & 8 \\
\hline مناسب & $\% 90.6$ & 3.01 & 2.7 & 1387 & 7 & 174 & 344 & 9 \\
\hline مناسب & $\% 98$ & 2.46 & $9 . .2$ & 1500 & & 189 & 374 & 10 \\
\hline مناسب & $\% 80.7$ & 4.7 & 2.4 & 1235 & 225 & 220 & 190 & 11 \\
\hline
\end{tabular}




\section{مجلة الاقتصاد المنزلى - مجلا (30)- العدد الأول - 2020 م}

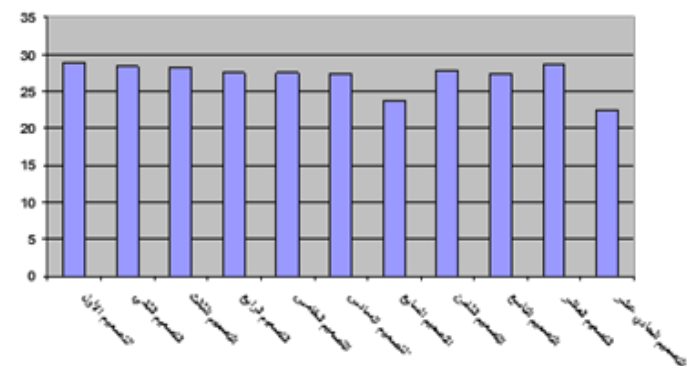

شكل (7) ترتيب التصميمات المقترحة وفق معاملات الجودة لآر اء المستهكات المات المقترحة

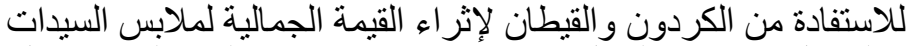
المقترحة من الجدول (18) والثكل (7) نجد: اتفاق اراء المستهلكات حول النصات التصميمات نجد ان تقييم معاملات الجودة للتصميمات المقترحة تكون مرتفعة حيث تبين ان عدد

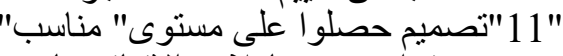

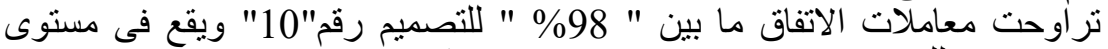

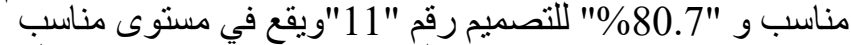

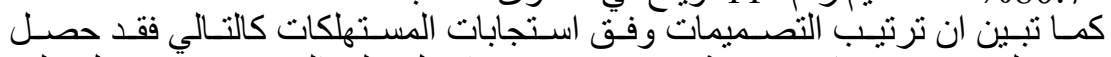

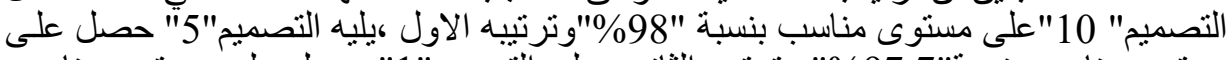

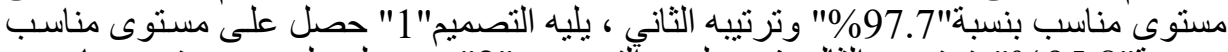

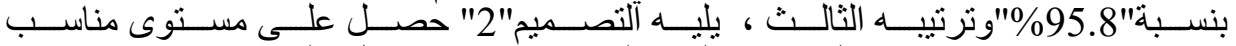

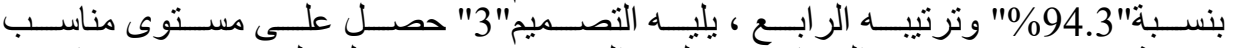

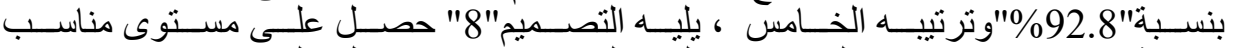

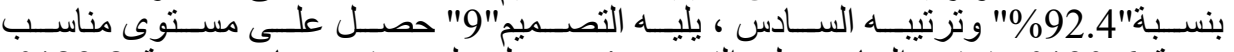

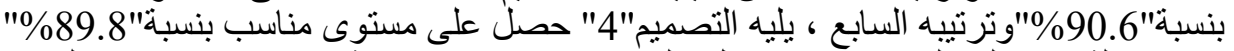

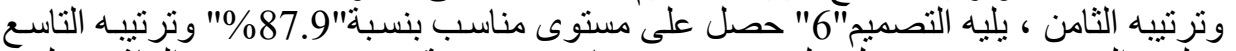

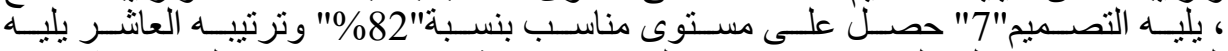

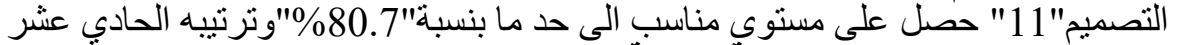

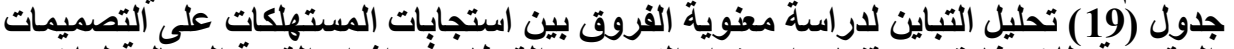

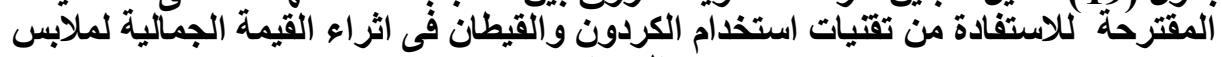
السيدات الكردون

\begin{tabular}{|c|c|c|c|c|c|c|c|}
\hline مستولة الدلاكي & اللالالة & $\mathbf{F}$ & متوسط المربعات & المربعات & الحرجية & مصدر التباين & الاستباته ككل \\
\hline & \multirow[t]{3}{*}{0.000} & \multirow[t]{3}{*}{20.831} & 217.951 & 2179.508 & 10 & التصنميمات ين & \multirow{3}{*}{ 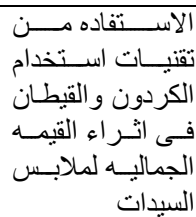 } \\
\hline & & & 10.463 & 5754.667 & 550 & داخصميمات & \\
\hline & & & & 7934.175 & 560 & الاجمالى & \\
\hline
\end{tabular}

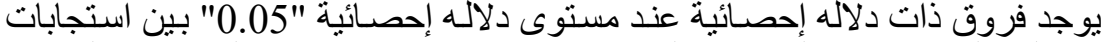

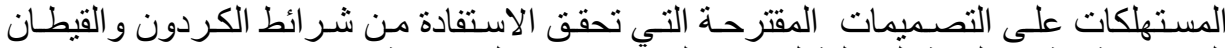
المستخدمة لإثراء القيمة الجمالية لملابس السيذّات حيث بلغت قيمة "ف " 20.831 


\section{مجلة الاقتصاد المنزلى - مجلد (30)- العدد الأول - 2020 م}

ومستوى الدلالة اقل من مستوى المعنوية "0.05" مما يدل على وجود فروق بين التصميمات

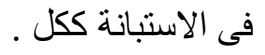

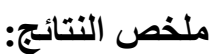

1- يوجد فروق ذات دلاله احصائيه عند مستوى دلاله احصـائيه "0.05" بين استجابات السـاده

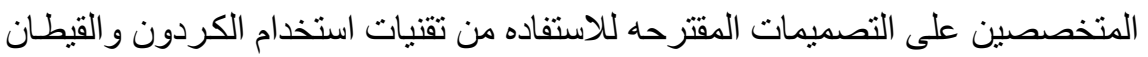

فى اثراء القيمه الجماليه لملابس السيدات حيث بلغت قيمة "ف ل " 1.480

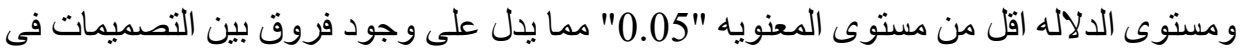

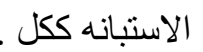

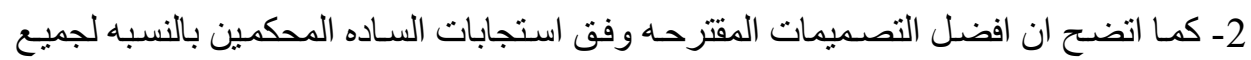

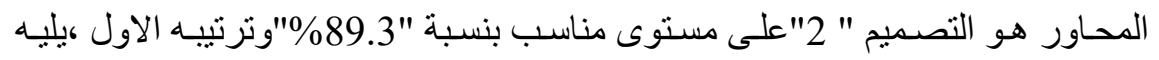

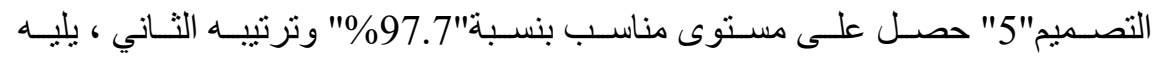

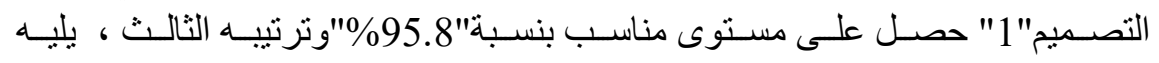

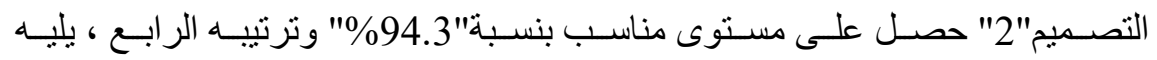
التصميم"3" حصل على مستوى مناسب بنسبة" 92.8\%"وترنيبه الخامس .

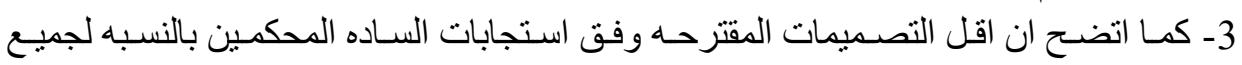

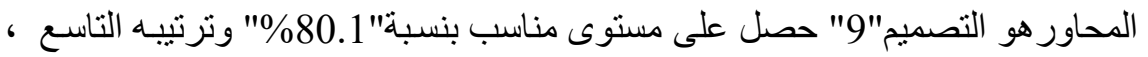
يليه التصميم"7" حصل على مستوى مناسب الى حد ما بنسبة" \%

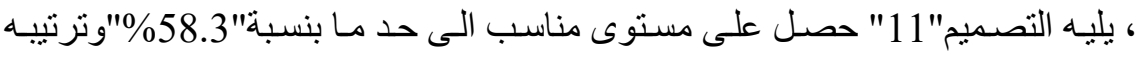
الحادي عشر.

1- الاهتمام بمجال التطريز واستخدام التقنيات الحديثة فى هذا المجال.

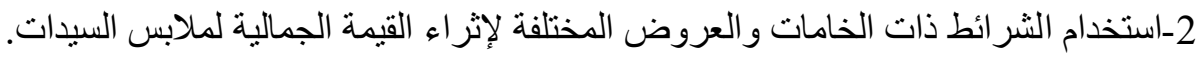

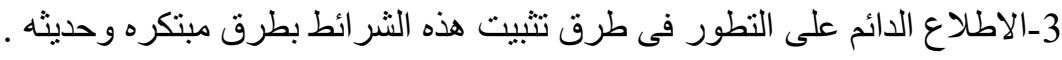

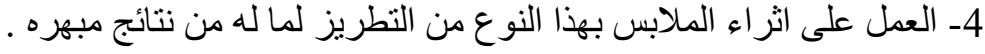

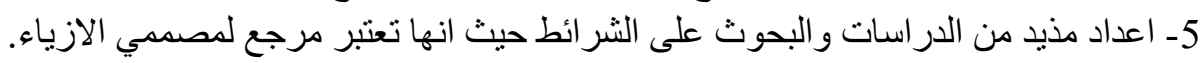

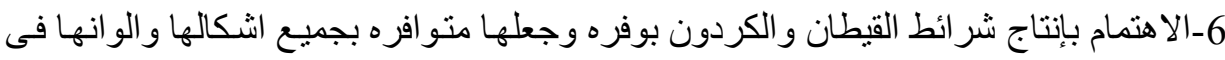




\section{مجلة الاقتصاد المنزلى - مجلد (30)- العدد الأول - 2020 م}

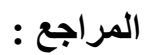

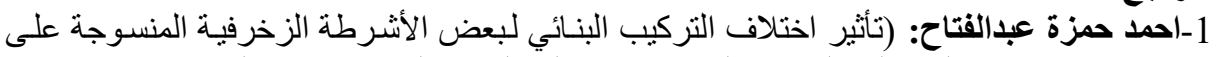

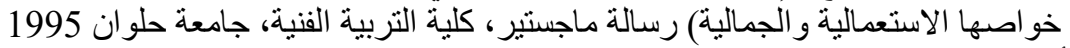

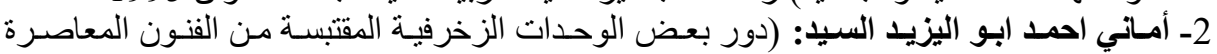

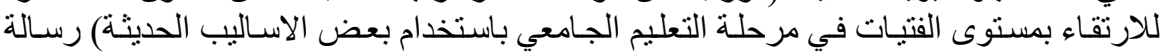

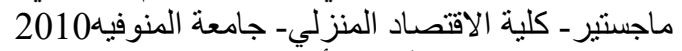

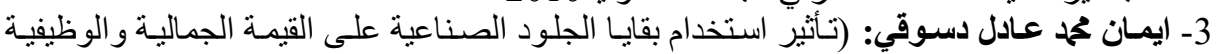

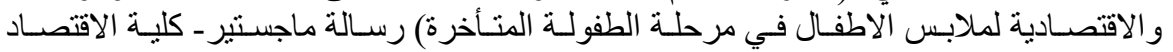

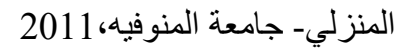

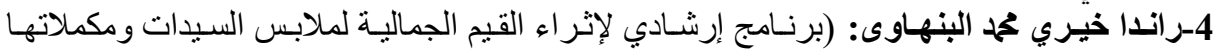

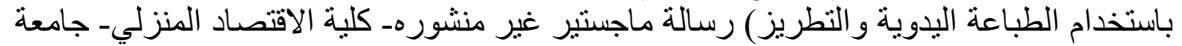

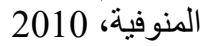

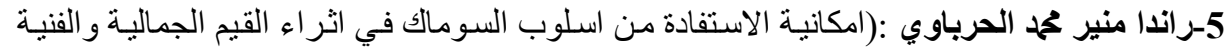

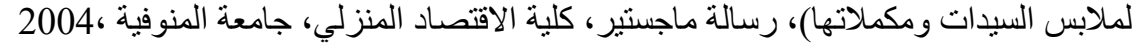

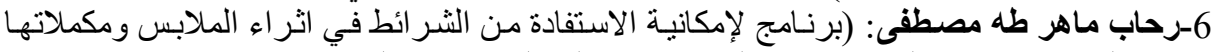

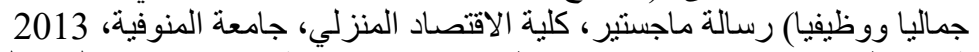

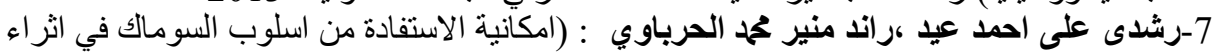

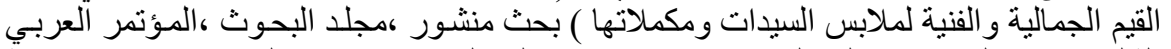

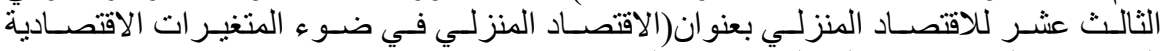

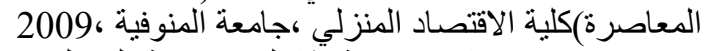

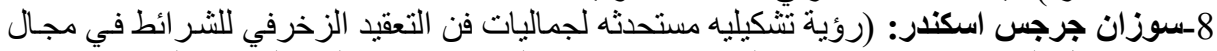

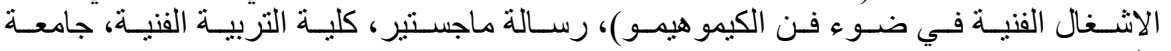

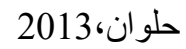
9- عبير جابر مصطفى حمحا: (توظيف الثر ائط الزخرفية الإسـلامية كمفردات تشكيليه لبناء مشغولة

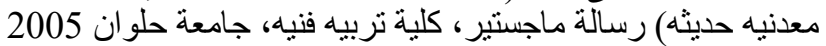

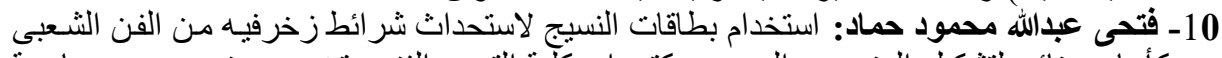

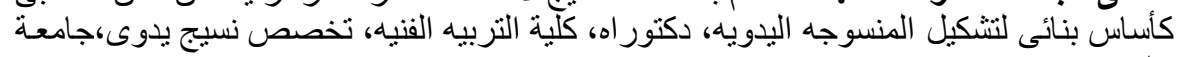

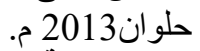

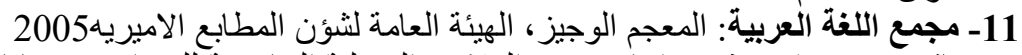

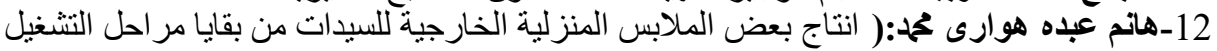

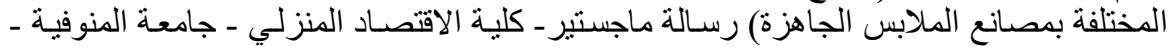
2004

13-هاله كحمة محمود حسين: (التحليل الجمالي لبعض الزخارف الفنبة في حضار ات العر اق القديم

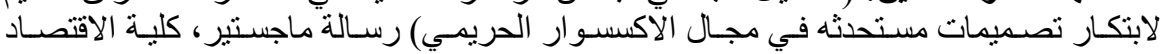

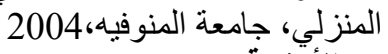
المراجع الأجنبية

-13Amiel Leon-: color ,New York ,2006

-14 Nancy Bednar : Sillk Ribbon Machine Embroidery prettyfulpatterns ،1997 -15 Jackie\&Daphnet j.Ashby_Woolsey 1998 


$$
\text { مجلة الاقتصاد المنزلى - مجلد (30)- العدد الأول - } 2020 \text { م }
$$

\title{
Benefit From The Techniques Of Using Cordon And Cord To Enrich The Aesthetic Value Of Women's Clothing
}

\section{Ola Youssef Mohamed Abdellah,Nashwa Abd Elraouf Tewfik, Eaman Abd Raboh Ramadan Rashed}

\begin{abstract}
:
The research aims to: a descriptive and analytical study to identify the types of cordon and cord and how to benefit from them and achieve aesthetic values by developing innovative and diverse designs and inserting them into different models suitable for women (21-35) years old and identifying how to combine both the cord and cordon and enriching the aesthetics of clothing by following a style Merging them Measuring the opinions of specialists in the proposed designs. 11 designs were prepared using the embroidery technique with cordon ribbons and cords. These designs were presented to a number of arbitrators and among the results of the study were the existence of statistically significant differences between the averages of the opinions of the arbitrators of the proposed designs
\end{abstract}


